\title{
Adventures in the Zone of Twilight: Separation of Powers and National Economic Security in the Mexican Bailout
}

\author{
Russell Dean Covey
}

\section{INTRODUCTION: WAS THE MEXICAN BAILOUT LEGAL?}

On January 12,1995 , President Clinton requested legislation providing $\$ 40$ billion in loan guarantees to prevent Mexico from defaulting on bonds worth billions of dollars. Less than three weeks later, the President preempted the ongoing congressional debate on the guarantees and, without any formal congressional action, unilaterally negotiated a combination of additional loans from international institutions (the International Monetary Fund (MMF) and the Bank for International Settlements (BIS)) and promised Mexico $\$ 20$ billion from the Exchange Stabilization Fund (ESF), an obscure revolving fund in the Treasury normally used to stabilize the dollar on world currency markets.'

It is far from clear that the President had the legal authority to take this action. While the administration claimed to be responding primarily to the dramatic devaluation of the peso, the main purpose of the loans was not to restore the value of Mexico's currency, but to prevent its looming default on dollar-denominated securities threatened by the depletion of its hard-currency reserves, and thereby to boost confidence in Mexican markets and curtail

1. See David E. Sanger, International Package of Aid Could Reach About $\$ 50$ Billion, N.Y. TIMES, Feb. 1, 1995, at A1, Al6. The IMF originally pledged $\$ 17.8$ billion in loans. Canada agreed to deliver $\$ 2$ billion. Id. The IMF contribution was increased subsequently to $\$ 18.9$ billion. See The Mexican Peso Crisis, 1995: Hearings Before the Senate Comm. on Banking, Housing, and Urban Affairs, 104th Cong., Ist Sess. 601,619 (1995) [hereinafter Mexican Peso Crisis] (testimony of Lawrence Summers. Undersecretary of the Treasury). As of July 14, 1995, Mexico had also received $\$ 2.75$ billion from the Inter-American Development Bank and the World Bank. Id. at 635 . The $\$ 10$ billion in BIS loans remains available. Unlike the loan packages extended by the MMF and the United States, the BIS has refused to make monies available for anything other than short-term loans, and Mexico has preferred not to draw on those funds. ld. 
further capital flight. ${ }^{2}$ U.S. aid was extended not through intervention in exchange markets to prop up or stabilize the Mexican currency, but rather through a package of loans and loan guarantees provided directly to the Mexican government. ${ }^{3}$ The package was thus only incidentally an act of "currency stabilization," and is more accurately described as a grant of foreign aid. "In other words, it was a classic case of government "bailout," though one of virtually unprecedented magnitude. ${ }^{6}$

2. U.S. and International Response to the Mexican Financial Crisis, 1995: Hearings Before the House Comm. on Banking and Financial Senvices, 104th Cong., 1st Sess. 87, 93 (1995) [hereinafter Hearings Before the House Comm. on Banking, Feb. 9, 1995] (testimony of Robert Rubin, Secretary of the Treasury). The proceeds from the issuance of any debt securities are supposed "to facilitate the redemption, refinancing or restructuring of Mexico's short-term debt obligations." Guarantee Agreement Dated as of February 21, 1995 Among the United States Department of the Treasury, and the Government of the United Mexican States, State Dep't No. 95-135, available at 1995 WL 425201.

3. Technically, the aid package included "swaps," not loans. Swaps are agreements between governments to exchange IOU's of national currencies that give each partner the right to draw down on those currencies at any time. Practically speaking, the swap agreements function like loans in that Mexico receives dollars up front and faces an obligation to repay them at a later date. Though the United States holds a "certificate of indebtedness" from Mexico that it is free to cash in at any time, the purpose of the arrangement is to allow Mexico to gain access to dollars now in exchange for Mexico's promise to repay later. See Medium-Term Exchange Stabilization Agreement Between the United States and Mexico (Feb. 21, 1995), available at 1995 WL 425203.

4. The administration vigorously disputed this characterization, primarily on the grounds that Mexico is obligated to pay interest on all funds borrowed from the ESF and that the loans have been "secured" against Mexico's income from its oil reserves. Despite Mexico's paper guarantees and the potential for full repayment, taxpayer dollars were put at risk. Were this not true, Mexico could have acquired the loans on private markets without the need for U.S. government intervention. Additionally, even where no actual funds have been committed, as with the extension of loan guarantees, traditional budget-keeping mehods require that Congress make the requisite authorizations, since they may require outlays from the Treasury at some point in the future. As the Congressional Budget Ofrice has explained:

A default on a loan made by the ESF could affect the budget by lowering the amount of collections, primarily interest and fees, that the fund would have otherwise received. . . . [I]f the assisted country could not pay the interest, budgetary outlays would rise because the ESF would not receive collections. If the country defaulted on principal, the assets would eventually have to be written down by the amount of the currency's depreciation, and by any foregone interest, thereby raising future budgetary outlays. If defaults occurred on a large enough scale, the fund would have to either reduce the scope of its operations or seek additional capital.

Letter from Rudolph G. Penner, Director, Congressional Budget Office, to Stephen L. Neal, Chairman, Subcommittee on International Trade, Investment and Monetary Policy, U.S. House of Representatives (Apr. 30, 1984), in Exchange Stabilization Fund and Argentina, 1984: Hearings Before the Subcomm. on International Trade, Investment and Monefary Policy of the House Comm. on Banking, Finance and Urban Affairs, 98th Cong., 2d Sess. 15, 17 (1984) [hereinafter CBO Letter].

5. For a discussion of bailout history and policy, see Cheryl D. Block, Overt and Covert Bailouts: Developing a Public Bailout Policy, 67 IND. L.J. 951 (1992). According to Block, a bailout is defined as "a form of government intervention in another market arena." Id. at 955 . Though bailouts belong to the same conceptual family as general government subsidies, they provide benefits to a more concentrated group. The focus of a bailout is on saving a particular entity from collapse. Block distinguishes between overt and covert bailouts. The Mexican bailout, in Block's terms, is an "overt" bailout because it takes the form of "direct assistance, loans or loan guarantees." Id. at 968 . Covert bailouts, in contrast, are less visible and can be provided in a number of ways, including special tax breaks, trade restrictions, tariffs, and quotas. U.S. intervention in currency markets to prop up the peso would have constituted a type of covert bailout.

6. In the last 25 years, the United States has engaged in a number of large-scale public bailouts. Only one exceeded the magnitude of the $\$ 20$ billion rescue of the Mexican economy: the $\$ 500$ billion savings and loan bailout of 1989. The legislative vehicle for the S\&L bailout was the Financial Institutions Reform, Recovery, and Enforcement Act of 1989, Pub. L. No. 101-73, 103 Stat. 183. The controversial 1980 rescue of Chrysler required the United States to extend a mere \$1.5 billion. See COMPTROLLER GENERAL, 
In taking this unilateral action, President Clinton received praise from congressional leaders. ${ }^{7}$ Republican Speaker of the House Newt Gingrich called the action "courageous." Congressional leaders from both parties further agreed that the President had the statutory authority to deliver the funds to Mexico without any subsequent congressional authorization or appropriation. ${ }^{9}$

Nonetheless, a significant number of Senators and Representatives opposed the plan and questioned its legality. ${ }^{10}$ Ultimately unsuccessful attempts were made in both the House and Senate to prevent the package from proceeding or to curtail aid already being delivered."

Though the Mexican bailout is substantially complete, the doctrine of separation of powers requires a close look at the use of revolving funds like the one employed to aid Mexico, particularly when such funds are drawn on without congressional authorization. ${ }^{12}$ This Note argues that the ESF was

GUIDELINES For RESCUING LARge FaILING FIRMS AND MUNICIPALITIES, GAO/GGD 84-34, at 19 (Mar. 29 , 1984) [hereinafter GAO REPORT]. Other large bailouts include the $\$ 250$ million rescue of Lockheed in 1971, the $\$ 2.3$ billion rescue of New York City in 1975, and a subsequent $\$ 1.65$ billion bailout in 1978 . Id. In 1984, the federal government orchestrated a $\$ 7.5$ billion rescue of Continental Illinois, the eighthlargest bank in the nation. Funding was provided through the Federal Deposit Insurance Corporation-which gets its money from insurance premiums paid by private banks-and thus no money was taken from the Treasury. See Peter T. Kilbom, Where the Rescue Money Comes From, N.Y. TIMES, May 19, 1984, at A33. To appreciate fully the scope of the $\$ 20$ billion Mexican bailout, one need only note that the entire foreign-aid budget passed by Congress for 1996 is only $\$ 12.1$ billion. See George Moffett, Skeptical Congress Accelerates Foreign-Aid Cuts, Charging Waste and Poor Returns, CHRISTIAN SCI. MONITOR, Nov. 30, 1995, at 4.

7. See George Graham, Republicans to Clinton Rescue, FIN. TIMES, Feb. 8, 1995, at 6.

8. See Nancy E. Roman, Mexico Plan Causes GOP Rift, WASH. TIMES, Feb. 2, 1995, at AI.

9. See President's Statement with Congressional Leaders on Financial Assistance to Mexico, 31 WEEKLY COMP. PRES. DOC. 155 (Jan. 31, 1995) [hereinafter Joint Statement] ("We agree that, in order to ensure orderly exchange arrangements and a stable system of exchange rates, the United States should immediately use the ... ESF ... to provide appropriate financial assistance for Mexico. We further agree that under . . . Section 5302, the President has full authority to provide this assistance."). The statement was signed by Newt Gingrich, Speaker of the House; Bob Dole, Senate Majority Leader; Thomas Daschle, Senate Minority Leader; Richard Armey, House Majority Leader; and Richard Gephardt, House Minority Leader. Id.

10. See, e.g., Oversight on the Monetary Policy Report to Congress Pursuant to the Full Employment and Balanced Growth Act of 1978: Hearings Before the Senate Comm. on Banking, Housing, and Urban Affairs, 104th Cong., 1st Sess. 1-2 (1995) [hereinafter Hearings Before the Senate Comm. on Banking, Feb. 22, 1995] (statement of Sen. Alfonse D'Amato); Major Garrett, House Leaders to Allow Debate on Peso Bailout, WASH. TIMES, Feb. 14, 1995, at A1; Rex Nutting, Opponents Try to Stop Mexico Aid, UPI, Feb. 6, 1995, available in LEXIS, News Library, UPI File; Roman, supra note 8.

11. Both the House and Senate passed bills in reaction to the Mexican bailout. Senator D'Amato authored an amendment to prevent the President from using the ESF as he did in the Mexican crisis. However, the measure specifically did not apply to the Mexican bailout. See Jonathan D. Glater, D'Amato Wins an Anti-Bailout Measure, WASH. PosT, Aug. 6, 1995, at A17. In July, the House passed legislation to cut off further funding of the Mexican bailout. See House Votes to Block More Mexico Loans, CHI. TRIB., July 20, 1995, at 16. The measure was incorporated from a bill introduced by Representative Bernie Sanders, $i d$., providing that "certain budget authority and credit authority provided to the Exchange Stabilization Fund shall be effective only to the extent provided in appropriation acts." H.R. 867, 104th Cong,, 1st Sess. (1995). Earlier, the House approved a resolution introduced by Representative Marcy Kaptur requesting the President to submit information "concerning actions taken through the exchange stabilization fund to strengthen the Mexico peso and stabilize the economy of Mexico." H.R. 80, 104th Cong., 1st Sess. (1995).

12. Similar issues are raised by the President's negotiation of emergency provisions with the Japanese central bank in the event of a Japanese banking crisis. See Keith Bradsher, Fearing Japanese Bank Frailty, 
used improperly and that, despite the informal approval of congressional leaders, President Clinton had neither statutory nor constitutional authority to extend the aid package to Mexico in the absence of a formal congressional appropriation. Though the President's admittedly substantial latitude to act in matters affecting national security might have provided him with the emergency authority to preempt the legislative process and spend unappropriated dollars, this Note argues that such preemption remains illegal, at least until Congress ratifies the appropriation retroactively. ${ }^{13}$

Part I examines the statutory authority claimed by the administration to fund the bailout. It argues that the statute relied upon by the President, ${ }^{14}$ the legislative history of the relevant provisions, the historical use of the ESF, and statements made by administration officials all indicate that there was no statutory authorization for the administration's use of the Fund. Part II analyzes the constitutional issues raised by the bailout under the framework set forth by Justice Jackson in Youngstown Sheet \& Tube Co. v. Sawyer; it concludes that the President lacked the necessary constitutional authority Jackson's framework suggests must exist in the absence of congressional authorization. ${ }^{15}$ Even if authorization may be inferred through a more liberal interpretation of the statute's text and history, Congress has never established any "intelligible principle" to guide the use of the Fund. The bailout therefore also constitutes an impermissible delegation of legislative authority and, consequently, is constitutionally infirm.

While the Note argues that the unguided use of revolving funds constitutes an incursion on the congressional appropriations power and cannot be tolerated in a political regime of separated powers, national security concerns do require the President to retain administrative flexibility in order to perform the constitutional duties of Commander in Chief. This requirement is especially pertinent in light of recent transformations in communications technology and information systems that have caused significant changes in the nature of threats to national security. Part III recognizes that these changes, which have given rise to increasingly volatile and interdependent international financial markets, require the executive branch to have substantial discretion to obligate

U.S. Agrees to Give Future Help, N.Y. TIMES, Oct. 17, 1995, at Al (describing plan for Federal Reserve to provide money quickly to Japanese regulators if one or more Japanese banks run into trouble and need bailout during trading hours in United States).

13. Cf. Youngstown Sheet and Tube Co. v. Sawyer, 343 U.S. 579, 631 (1952) (Douglas, J., concurring) (noting that President might seize private property and Congress might subsequently ratify seizure, "[b]ut until and unless Congress acted, no condemnation would be lawful"); The Prize Cases, 67 U.S. (2 Black) 635, 670 (1862) (noting that Congress had ratified ex post Lincoln's potentially illegal seizure of foreign warships), discussed in Harold Hongju Koh \& John Choon Yoo, Dollar Diplomacy/Dollar Defense: The Fabric of Economics and National Security Law, 26 INT'L LAW. 715, 724 (1992); WILLIAM C. BANKS \& PETER RAVEN-HANSEN, NATIONAL SECURITY LAW AND THE POWER OF THE PURSE 134-36 (1994) (discussing relationship between necessity and legality).

14. See 31 U.S.C. $\$ 5302$ (1994).

15. 343 U.S. at 634 (Jackson, J., concurring). 
monies to protect the nation's financial integrity. However, procedural restraints on that discretion are necessary to ensure that Congress is not prevented from exercising its exclusive power of the purse. The interests of a functional but fair democratic system require a balance between these competing concerns. Accordingly, Part IV suggests ways to provide the President with clear authority to protect "economic security" while keeping Congress firmly in control of the purse strings.

\section{STATUTORY AUTHORITY FOR THE MEXICAN BAILOUT}

Of the three principal components of the bailout package, only one required a direct outlay from the U.S. Treasury: the $\$ 20$ billion that was obligated from the Exchange Stabilization Fund (ESF). The President has claimed statutory authority to spend ESF monies under 31 U.S.C. $\S 5302$, but neither the text of $\S 5302$ nor its legislative history supports this claim.

\section{A. The Text of $\$ 5302$}

Section 5302 authorizes the Secretary of the Treasury, with the approval of the President, to "deal in gold, foreign exchange, and other instruments of credit and securities the Secretary considers necessary." creates a revolving "Exchange Stabilization Fund." The revenues from its activities-proceeds from sales, investments, and earnings-are repaid into the Fund and remain available for future use absent any additional congressional appropriation. ${ }^{17}$ The Fund was created with a $\$ 2$ billion appropriation in 1934 , which, as of March 1995, had grown to roughly $\$ 37.5$ billion. $^{18}$

The text of the statute enumerates three purposes for which expenditures from the ESF are authorized. ${ }^{19}$ First, the Fund is available to meet U.S. obligations under the Bretton Woods Agreement. ${ }^{20}$ Second, the Fund provides a mechanism to carry out U.S. obligations under $\S 3$ of the Special Drawing Rights Act. ${ }^{21}$ Third, the Fund is available, in the opaque language of the

16. 31 U.S.C. $\$ 5302($ b) (1994).

17. Id. $\$ 5302(\mathrm{a})(1)$.

18. See Mexican Peso Crisis, supra note 1, at 371 (testimony of Robert Rubin, Secretary of the Treasury). But according to Rubin, only $\$ 29.5$ billion was "usable." Id.

19. See 31 U.S.C. $\$ 5302(\mathrm{a})(1)$ (1994).

20. "The Articles of Agreement require the United States to maintain the value of IMF holdings of dollars in terms of the IMF's unit of account (formerly gold, currently, the SDR)." S. REP. No. 698, 95th Cong., 2d Sess. 14 (1978), reprinted in 1978 U.S.C.C.A.N. 2565, 2578. One of the principal obligations was established by Article IV of the amended Articles of Agreement, which requires members to "avoid manipulating exchange rates or the international monetary system in order to prevent effective balance of payments adjustment or to gain an unfair competitive advantage over other members." S. REP. No. 1295, 94th Cong., 2d Sess. 6 (1976), reprinted in 1976 U.S.C.C.A.N. 5950, 5955.

21. 22 U.S.C. $\$ 286(0)$ (1994). Special Drawing Rights (SDRs) are units of account established by the IMF representing the value of a "basket" of currencies designated by the IMF. Countries experiencing current account shortages can borrow foreign currencies from other central banks by depositing or 
statute, "to carry out this section." 22 However, since there is no further specification of the purposes of $\S 5302$ beyond its title- "Stabilizing exchange rates and arrangements"- - one must turn to the legislative history of $\S 5302$ to determine what further purposes might be incorporated into "this section."23

\section{B. Legislative History of $\$ 5302$}

The ESF was originally created as part of the Gold Reserve Act of 1934 by a New Deal Congress intent on protecting the dollar on international exchange markets. The Fund, once described as "the most ingenious instrument ever developed in the monetary systems," 24 was inspired by fears that rival trading nations, particularly Britain, but also France, Italy, and Germany, would capture large segments of the world market by deflating their own currencies relative to the dollar. As explained in a House committee report, "The reason for its establishment in this case is to defend the American dollar and our gold stocks against the invasion of similar funds operated by competitor nations." A British fund, established months earlier in an amount equivalent to $\$ 175$ million, the committee reported, "was so effective in driving our dollar up that we were forced off the gold standard. It is to prevent a repetition of this experience that we create the stabilization fund preparatory to the return to gold redemption.",25 Since 1934, the law has been amended several times, ${ }^{26}$ but none of the changes in the authorizing language have substantially altered its intended purpose: to allow the government to protect the dollar and maintain desirable exchange rates against foreign currencies.

The most significant alteration in the law's language was made in 1976 following the collapse of Bretton Woods and the accompanying shift from

exchanging SDRs in return for those currencies. SDRs that the IMF has allocated to the United States are held in the ESF, which "pays and receives SDR charges and interest and meets U.S. commitments to purchase SDRs from other countries." CBO Letter, supra note 4, at 17.

22. 31 U.S.C. \$ 5302(a)(1) (1994).

23. Review of Treasury Department's Conduct of International Financial Policy: Hearings Before the House Comm. on Banking, Finance and Urban Affairs, 101st Cong., 2d Sess. 3 (1990) [hereinafter Hearings Before the House Comm. on Banking, Aug. 14, 1990] (discussing amendment to give GAO audit authority over all ESF operations).

24. H.R. ReP. No. 292, 73d Cong., 2d Sess. 2 (1934).

25. S. REP. No. 201, 73d Cong., 2d Sess. 201, 204 (1934) (quoting H.R. REP. No. 292, 73d Cong., $2 d$ Sess. 1, 3 (1934)). "It is generally understood that the United States needs this equalization fund in order to compete with a similar fund which Great Britain has and is using." Id. at 201.

26. The ESF originally was established as a temporary fund, authorized for two years with the option of renewal by the President for a third. The Fund was renewed periodically by Congress until 1943. As part of the Bretton Woods Agreements Act of 1945, the ESF became a permanent fund, although its size was reduced by $\$ 1.8$ billion, which was part of the United States's original subscription to the IMF. See H.R. REP. No. 629. 79th Cong., 2d Sess. 3 (1945). A 1962 amendment to the Bretton Woods Agreements Act provided that gold or currency purchases could be transferred to and administered by the ESF. Pursuant to the Special Drawing Rights Act of 1968, SDRs were denominated as official reserve assets and obligations, and receipts stemming therefrom were assigned to the ESF. See Letter from Edward S. Knight, General Counsel, Department of the Treasury, to Robert E. Rubin, Secretary of the Treasury, in Mexican Peso Crisis, supra note 1 , at $435,437-38$. 
fixed to floating exchange rates. Whereas the original language of $\S 10$ (a) of the Act authorized the Secretary of the Treasury to use the resources of the Fund "for the purpose of stabilizing the exchange value of the dollar," Congress amended the law to authorize the Secretary of the Treasury to use the ESF "as he may deem necessary to and consistent with the United States' obligations in the International Monetary Fund. ${ }^{32}$ This change was justified because "under the amended IMF Articles of Agreement there is no obligation to stabilize the dollar at a par value." ${ }^{29}$ Though the amendment reflected the new international monetary situation, it did not substantively expand the range of authorized uses of the ESF. Rather, it provided statutory recognition of the Nixon administration's 1971 decision to adopt a floating-exchange-rate regime. ${ }^{30}$ Legislative history, in fact, indicates that Congress intended this amendment to restrict the acceptable purposes of the ESF. According to the Senate report, "use of the ESF would be authorized only for purposes consistent with the United States obligations in the IMF regarding orderly exchange arrangements and a stable system of exchange rates." ${ }^{131}$ The amendment's language requiring consistency with orderly exchange arrangements prohibits aggressive use of the ESF to alter exchange rates unilaterally, a use that was permissible-and, in fact, envisioned-under the original language of the Gold Reserve Act.

The strongest support for presidential authority to extend ESF funds for purposes like the Mexican bailout is contained in comments explaining emergency provisions added by the 1976 amendment. These provisions allow, under certain circumstances, for the obligation of ESF monies for periods exceeding six months. ${ }^{32}$ According to the report:

The Committee recognizes that there may be circumstances where longer-term ESF credits may be necessary, and the amendment provides for that possibility. But the Committee intends, and the

27. Gold Reserve Act of 1934, ch. 6, $\$ 10(a), 48$ Stat. 337, 341 .

28. See Pub. L. No. 94-564, 90 Stat. 2660, 2661 (1976). For a discussion of the nature of U.S. obligations in the IMF, see KENNETH W. DAM, THE RULES OF THE GAME: REFORM AND EVOLUTION IN THE INTERNATIONAL MONETARY SYSTEM 115-72 (1992).

29. S. REP. No. 1148, 94th Cong., 2d Sess. 9 (1976), reprinted in 1976 U.S.C.C.A.N. 5935, 5943.

30. For a discussion of the background of Nixon's decision to "close the gold window," see United States v. Yoshida International, Inc., 526 F.2d 560, 567-69 (C.C.P.A. 1975).

31. S. REP. No. 1295, 94th Cong., 2d Sess. 17 (1976), reprinted in 1976 U.S.C.C.A.N. 5950, 5966 (emphasis added). While the prevention of government loan default and the maintenance of stable exchange rates are undoubtedly linked, linkage alone cannot provide sufficient rationale for the expenditure of ESF funds under the terms of $\$ 5302$. If it could, ESF funds could be employed for a wide range of purposes nominally linked to the movement of exchange rates. For instance, donations could be made to the PRI, Mexico's governing party, on the theory that a change in governing parties could have dramatic consequences for exchange rates. Such initiatives, however, obviously would exceed the authority of the Secretary of the Treasury.

32. The emergency provisions are contained in 31 U.S.C. $\$ 5302$ (b) (1994), which reads: "[A] loan or credit to a foreign entity or government of a foreign country may be made for more than 6 months . . . only if the President gives Congress a written statement that unique or emergency circumstances require the loan or credit be for more than 6 months." 
amendment expressly provides, that such longer-term financing be provided only where there are unique or exigent circumstances [including] . . . natural disasters, trade embargoes, unforeseen economic developments abroad, ... or other catastrophic events. ${ }^{33}$

The administration relied heavily on this language to support the bailout.

A broader view of the legislative history makes overreliance on this passage unwise, however. First, when the amendment was passed, the ESF was significantly smaller in asset value, ${ }^{34}$ and it is extremely doubtful that Congress foresaw its subsequent dramatic growth. ${ }^{35}$ Second, the report's language does not indicate that ESF monies can be used for any purpose whatsoever, even when such an unforeseeable catastrophe occurs. As it makes clear, "[t]he purpose of the Exchange Stabilization Fund is to provide shortterm credit to foreign countries to counter exchange market instability."36

Most importantly, when such expenditures are necessary, the report makes explicit that "all medium and longer-term financing" should be arranged "within the framework of the IMF or other appropriate multilateral facilities." ${ }^{37}$ No such provisions were made for the $\$ 20$ billion that was taken directly from the ESF. It is true, as the administration argues, that use of the ESF does not contravene IMF policies since the IMF was a coparticipant in the Mexican bailout. ${ }^{38}$ But that fact does not obviate the need for congressional appropriations. Specific ESF operations are not treated as expenditures because they usually involve "the exchange of one liquid asset for another." 39 The short-term nature of the loans and the requirement of assured repayment

33. S. REP. No. 1295, 94th Cong., 2d Sess. 11 (1976), reprinted in 1976 U.S.C.C.A.N. 5950, 5960.

34. In 1977 , the ESF contained approximately $\$ 4.0$ billion in assets. Id. Major growth in ESF holdings occurred in 1989 and 1990, following intervention sales of dollars pursuant to a coordinated devaluation of the dollar. See Hearings Before the House Comm. on Banking, Aug. 14, 1990, supra note 23, at 67 (prepared statement of David C. Mulford, Undersecretary of the Treasury).

35. As Representative Kaptur argued, "This particular commitment was 20 times as large as any prior use of this fund. Never has it been the will of this Congress to provide the executive branch with unlimited authority of this sort." 141 CONG. REC. 7217 (1995).

36. S. REP. No. 1295, 94th Cong., 2d Sess. 17 (1976), reprinted in 1976 U.S.C.C.A.N. 5950, 5966. As the report explained, "the Committee has adopted an amendment emphasizing the intended short-term nature of ESF lending. The goal is for the United States to place primary reliance on the IMF and to confine foreign exchange lending operations outside the IMF to short-term operations." Id. at 11 , reprinted in 1976 U.S.C.C.A.N. at 5960. As the CBO explained in 1984, "The ESF enables the Secretary to help equilibrate the exchange market in general and to provide short-term assistance to particular countries experiencing balance of payments problems." CBO Letter, supra note 4, at 16 (emphasis added).

37. S. REP. No. 1295, 94th Cong., 2d Sess. 11 (1976), reprinted in 1976 U.S.C.C.A.N. 5950, 5960.

38. See Memorandum from Walter Dellinger, Assistant Attorney General, to Edward S. Knight, General Counsel, Treasury Department (Mar. 2, 1995), in Mexican Peso Crisis, supra note 1, at 454-57.

39. CBO Letter, supra note 4, at 16. As one congressional witness testified, in contrast to the Federal Reserve Foreign Exchange Operations stated policy of investing

foreign currency balances in a variety of instruments that yield market-related rates of return and have a high degree of liquidity and credit quality ... . [i]t certainly cannot be said that the loans to Mexico have a high degree of liquidity; moreover, the current crisis was triggered largely by the fact that the Mexican government was about to default on its debts.

Mexican Peso Crisis, supra note 1, at 293 (prepared statement of John Mueller, Vice President and Chief Economist, Lehrman Bell Mueller Cannon, Inc.). 
eliminate the primary sources of risk and thus justify the budgetary treatment of such loans as financial arrangements rather than government expenditures. In addition, the fact that the long-term provisions were extended as loan guarantees rather than loans does not solve the legal problem. The extension of loan guarantees to foreign governments is a regular component of U.S. foreign policy and, like most kinds of foreign aid, requires congressional approval. ${ }^{40}$

The size and duration of the Mexican bailout make its authorization, based on either text or legislative history, highly doubtful. Certainly, it is unlikely that Congress was aware that, in passing the emergency provisions contained in the 1976 amendment, it was giving the President unchecked discretion over a fund that would grow to nearly three times the size of the total annual foreign aid budget. ${ }^{41}$

\section{Use of the Exchange Stabilization Fund}

Even if Congress has not provided the executive branch with explicit authority to engage in a particular activity, the Supreme Court has indicated that authority can be gleaned from a pattern of congressional silence in the face of a longstanding administrative practice. In the words of Justice Frankfurter:

[A] systematic, unbroken, executive practice, long pursued to the knowledge of the Congress and never before questioned, engaged in by Presidents who have also sworn to uphold the Constitution, making as it were such exercise of power part of the structure of our government, may be treated as a gloss on "executive Power" vested in the President by $\S 1$ of Art. II. ${ }^{42}$

If the Clinton administration's use of the ESF to bail out Mexico is consistent with past uses of the Fund, then even in the absence of authorizing language, the bailout might be deemed "implicitly" authorized. But an examination of the

40. "For most programs, direct loan obligations and loan guarantee commitments cannot be made unless Congress has appropriated funds for the costs in advance in annual appropriation acts." OFFICE OF MANAGEMENT AND BUDGET, BUDGET SYSTEM AND CONCEPTS OF THE UNITED STATES GOVERNMENT 22 (Feb. 1995). For instance, after much bitter debate in 1991, Congress approved $\$ 10$ billion in loan guarantees to Israel to assist in housing a large influx of Russian immigrants. See Thomas L. Friedman, Bush Makes Aid to Israel Subject to Conditions, N.Y. TIMES, Oct. 6, 1991, at D3. As Representative Christopher Cox noted in the Mexican bailout debate, "We had a nationwide debate on whether to give $\$ 10$ billion, half the amount [provided to Mexico], in Ioan guarantees to Israel. . . . [T] hat is the way these decisions should be made." 141 CoNG. REC. H7219 (daily ed. July 19, 1995) (statement of Rep. Cox).

41. The proposed foreign aid budget for 1996 is $\$ 12.1$ billion. See Moffett, supra note 6. As of March, 1995 , the assets of the ESF had grown to $\$ 37.5$ billion. See Mexican Peso Crisis, supra note 1, at 371 (testimony of Robert Rubin, Secretary of the Treasury).

42. Youngstown Sheet \& Tube Co. v. Sawyer, 343 U.S. 579, 610-11 (1952) (Frankfurter, J., concurring). 
practical operation of the Fund provides little indication of any "systematic, unbroken, executive practice" of using it for purposes like the Mexican bailout.

Early in its history, the ESF was defended as a useful tool in wartime foreign policy; ${ }^{43}$ it was then employed only sparingly during the 1950 s and 1960s. ${ }^{44}$ After 1977, use of the Fund increased, as the ESF was tapped to make loans to a wide range of countries, including the United Kingdom, ${ }^{45}$ Mexico, Turkey, Argentina, Israel, and Portugal. ${ }^{46}$ In only one instance was a loan extended beyond the statutory six-month limitation, triggering the requirement that the President submit to Congress a letter declaring urgent or emergency conditions. ${ }^{47}$ In 1982, President Reagan issued such a letter to Congress to extend a $\$ 600$ million ESF loan to Mexico beyond six months. ${ }^{48}$ The amount of funds made available to Mexico in 1982, however, was small in comparison to the 1995 aid package. The 1982 Mexican loans also did not exceed one year, whereas the current plan extends credit for up to five years and guarantees for up to ten. ${ }^{49}$

Although the Fund seems to have served as a flexible tool of foreign policy since its creation, there is no evidence that it has ever been used (except perhaps for the 1982 Mexico loans) in a manner deviating substantially from its initial purpose-protection of the dollar against foreign manipulation and the maintenance of an orderly system of exchange rates. ${ }^{50}$ In addition, though loans to foreign governments have been extended from the ESF on several

43. For instance, in 1941, the United States signed an agreement with China "making available $\$ 50,000,000 \ldots$ for the purpose of stabilizing the dollar-yuan rate of exchange." S. REP. No. 475,77 th Cong., Ist Sess. 2 (1941). According to the Senate Committee on Banking and Currency report, "These stabilization arrangements with China should be of great aid to China in her monetary problems and also in the struggle with the [Japanese] puppet currencies." Id. A similar arrangement for $\$ 50$ million was negotiated with Argentina in 1940 . The Senate reported that "[ $t]$ he machinery of the stabilization fund was most opportunely at hand to enable our Government to help prevent a prospective drain of foreign exchange resources from Argentina, as well as from other Latin-American countries." Id. The Committee report also noted that " $[t]$ he existence of the stabilization fund . . . made it possible to carry out with essential speed and secrecy three large acquisitions of gold from hard-pressed friendly countries." $I d$. 7607.

44. See H.R. REP. No. 1126, 95th Cong., 2d Sess. 1 (1978), reprinted in 1978 U.S.C.C.A.N. 7606,

45. S. REP. No. 1295, 94th Cong., 2d Sess. 11 (1976), reprinted in 1976 U.S.C.C.A.N. 5950, 5960.

46. United States Economic Programs for Poland and Hungary, 1989: Hearings and Markup Before the House Foreign Affairs Comm., 101st Cong., 1st Sess. 1 (1989) [hereinafter Hearings Before the House For. Aff's Comm., Oct. 4, 1989] (comments of Rep. Hamilton). Between 1982 and 1994, the ESF was used 40 times to provide financing agreements to 18 countries. The biggest recipients were Mexico, Brazil, Argentina, Venezuela, Bolivia, and Peru. See The Mexican Peso Bailout: Joint Hearing Before the Subcomms. on International Economic Policy and Trade and The Western Hemisphere of the House Comm. on International Relations, 104th Cong., 1st Sess. 61 tbl. 1 (1995) [hereinafter Joint Hearing].

47. See supra note 32 .

48. See Letter from the President to the Speaker of the House and the President of the Senate, 18 WEEKLY COMP. PRES. DOC. 1102 (Sept. 8, 1982).

49. See Hearings Before the Senate Comm. on Banking, Feb. 22, 1995, supra note 10, at 1 (statement of Sen. D'Amato).

50. Although, in the mid-1960s, the ESF was allegedly used "to prop up [the British] sterling in exchange for a commitment from the Wilson government to delay the withdrawal of British forces from Singapore." Ambrose Evans-Pritchard, Bill Clinton Goes For Broke, SundAY TELEGRAPH (London), Feb. 5, 1995, at 23. 
occasions, those loans never approached the size of the 1995 Mexican deal, ${ }^{51}$ they were not extended for longer than one year, ${ }^{52}$ and they have only been extended when backed by assured sources of repayment. ${ }^{53}$ Thus, though the 1982 incident provides some precedent for a bailout-like use of the Fund, authority for such a use seems tenuous. One arguably improper use can hardly be said to constitute "a systematic, unbroken practice."

\section{Executive Branch Interpretation of $§ 5302$}

Furthermore, congressional testimony given by executive branch officials has, on more than one occasion, expressly refuted the notion that ESF monies can be tapped to pay for general foreign aid objectives. In 1989, the House Committee on Foreign Relations held hearings regarding developments in Eastern Europe. At that time, members of the House panel were interested in extending a foreign aid package to Poland to assist with its transition to a market economy. Looking to circumvent the cumbersome appropriations process, committee members suggested that monies be taken directly from the ESF $^{54}$ Treasury officials explicitly denied that the ESF could be used to provide Poland with a package of long-term loans, ${ }^{55}$ reasoning that while

[w]e've used the Fund for intervention [in] exchange markets and for very short-term loans, usually bridged to a guaranteed repayment . . . . $[t]$ he proposal to provide Exchange Stabilization funds to Poland on a longer-term basis is a totally different use of the funds. That is much closer to foreign aid .... We think, therefore, it should be appropriated. $^{56}$

51. See Joint Hearing, supra note 46 , tbl. 1 (indicating that largest previous loans from ESF were a $\$ 1$ billion loan in August 1982 and two $\$ 600$ million loans, in September of 1982 and March of 1990, all to Mexico).

52. See id.; David E. Sanger, D'Amato Seeks to Limit Foreign Bailouts, N.Y. TIMES, July 22, 1995, at 34; see also Mexican Peso Crisis, supra note 1, at 404 (statement of Paul A. Volcker) ("To be sure, present arrangements with respect to Mexico are without precedent in size and nature.").

53. According to a House report, the ESF can be used "to extend short-term credits to foreign governments when such credits are backed by assured sources of repayment." H.R. REP. No. 1126, 95th Cong., 2d Sess. 2 (1978), reprinted in 1978 U.S.C.C.A.N. 7606, 7607.

54. See Hearings Before the House For. Aff's Comm., Oct. 4, 1989, supra note 46, at 162 (comments of Rep. Hamilton). "I think Poland needs a large infusion of money right away, very quickly, and cannot wait, frankly, for a negotiation of an IMF agreement and cannot wait, really, for the legislative process even to move forward ...." Id. at 164 .

55. See id. at 148 (testimony of William E. Barreda, Deputy Assistant Secretary for Trade and Investment Policy, Department of the Treasury). "Treasury requires an assured source of repayment in order to minimize exposing the ESF to a loss which would impact U.S. taxpayers. ... A prospective disbursement under an economic adjustment program supported by the International Monetary Fund and prospective disbursements from the World Bank are preferred sources." Id. at 163. Treasury officials also indicated that ESF funds were loaned only when there was assurance of repayment in hard currency. See $i d$. at 162. Instead, the Bush administration supported the creation of a separate fund for Poland and insisted that "the appropriate way" to create such a fund "is through an appropriation by Congress." Id. at 148.

56. Id. at 148-49. 
Treasury's former view that the ESF is available only for limited purposes prevailed up to the eve of the Mexican bailout. On January 26, 1995, just five days before the announcement of the bailout package, Federal Reserve Chairman Alan Greenspan testified to this effect while lobbying Congress to pass the legislative package of loan guarantees to Mexico. ${ }^{57}$ When asked why congressional appropriations were needed, Greenspan responded that the administration had already considered and rejected the use of funds from the Federal Reserve or the Treasury. "The reason, actually, that we supported the issue of going for another approach to this is largely that we do not have authorities as we see it-either in the ESF at the Treasury or at the Federal Reserve." 58

The testimony of Treasury Department officials and Chairman Greenspan suggests that statutory authorization for the Mexican bailout has been widely assumed to be lacking. As I will discuss below, the testimony is even stronger evidence that the statute-even assuming that the 1995 deployment of ESF funds to Mexico had been "authorized"-contains no meaningful guidance as to the boundaries of that authorization.

\section{CONSTItUTIONALity AND THE SEPARATION OF POWERS}

The foregoing analysis indicates that statutory authority for the $\$ 20$ billion Mexican bailout was lacking. However, a myopic focus on the nuances of statutory interpretation obscures larger issues about the structure of our constitutional system. How extensive are the President's powers to respond to international economic crises in the absence of decisive congressional action? Has Congress in effect ceded the field of emergency economic assistance to the executive branch? If so, does the President then assume or retain an inherent power to make appropriations?

Youngstown Sheet \& Tube Co. v. Sawyer ${ }^{59}$ provides an apt precedent for analysis of these questions. The conflict presented in Youngstown derived from an executive order issued by President Truman authorizing government seizure of the nation's steel mills following a lengthy labor dispute. ${ }^{60}$ Truman claimed that national security concerns stemming from the conflict in Korea and the centrality of the steel industry to national defense necessitated the extraordinary presidential decree. ${ }^{61}$ The Supreme Court disagreed. Only a few years before, Congress had debated and passed legislation providing for the

57. U.S. Economic Outlook: Hearings Before the Senate Budget Comm., 104th Cong., Ist Sess. (1995), available in LEXIS, News Library, Curnws File.

58. Id.

59. 343 U.S. 579 (1952).

60. Id. at 582 .

61. Exec. Order No. 10,340, 17 Fed. Reg. 3139 (1952), reprinted in 1952 U.S.C.C.A.N. 1043. 
resolution of labor disputes. ${ }^{62}$ Finding that Congress had contemplated but expressly demurred from authorizing presidential seizure of strike-frozen enterprises, the Court held that Truman's action was an unconstitutional usurpation of congressional authority. ${ }^{63}$

In his concurring opinion, Justice Jackson articulated a theory of presidential power that retains force today. ${ }^{64}$ Jackson's theory described three possible configurations, or "zones," of legal authority, based on the proposition that no executive action can be legal unless it is authorized by either the Constitution or Congress. ${ }^{65}$ In zone one, Congress has authorized executive action, and the President therefore acts with the greatest degree of authority. ${ }^{66}$ In zone two, which Jackson described as a "zone of twilight," Congress has neither expressly authorized nor clearly prohibited presidential action. ${ }^{67}$ In zone three, Congress has either prohibited or specifically refused to authorize executive action, giving rise to a direct conflict between Congress's powers and the President's independent constitutional authority. As Jackson noted, when acting in zone three, the President's authority is "at its lowest ebb."68

An application of Jackson's model to the Mexican bailout produces two possible analytical postures. First, if the bailout was authorized by Congress, it falls into zone one, making unnecessary any investigation into the President's independent constitutional powers. Such a finding, however, does not resolve the legal problem because allowing the President unsupervised discretion to bail out foreign countries raises critical issues under the nondelegation doctrine. The second possibility is that Congress had not provided the President with the statutory authority to effect the bailout, placing the bailout beyond zone one. In either zone two or three, the President must rely upon some source of independent, Article II authority, an authority this Note argues the President does not have.

62. See Labor Management Relations Act, 61 Stat. 136, 152-56 (1947) (codified as amended at 29 U.S.C. \$ 141 (1994)).

63. Youngstown, 343 U.S. at 589.

64. Id. at 634-38 (Jackson, J., concurring).

65. See id. at 635-38 (Jackson, J., concurring). See also Justice Black's majority opinion: "The President's power, if any, to issue the order must stem either from an act of Congress or from the Constitution itself." Id. at 585.

66. "When the President acts pursuant to an express or implied authorization of Congress, his authority is at its maximum, for it includes all that he possesses in his own right plus all that Congress can delegate." Id. at 635 (Jackson, J., concurring).

67. When the President acts in absence of either a congressional grant or denial of authority, he can only rely upon his own independent powers, but there is a zone of twilight in which he and Congress may have concurrent authority, or in which its distribution is uncertain. Therefore, congressional inertia, indifference or quiescence may sometimes, at least as a practical matter, enable, if not invite, measures on independent presidential responsibility.

Id. at 637 (Jackson, J., concurring).

68. "When the President takes measures incompatible with the expressed or implied will of Congress, his power is at its lowest ebb, for then he can rely only upon his own constitutional powers minus any constitutional powers of Congress over the matter." Id. (Jackson, J., concurring). 


\section{A. Zone One and the Nondelegation Doctrine}

Because the bailout has already been treated as statutorily authorized, an analysis under Jackson's zone one is relevant. Such a broad reading of $\S 5302$ is highly problematic, however, since it creates virtually unlimited opportunities for the President to make extraordinarily large expenditures from the public fisc in the absence of congressional guidance. Granted, constitutional precedent indicates that limitations on delegation of foreign affairs powers are few; ${ }^{69}$ the President retains a discretion to conduct foreign affairs that would not be tolerated in domestic matters. ${ }^{70}$ Nonetheless, such precedent does not foreclose the possibility that a delegation might be unconstitutional even in matters touching on foreign affairs. ${ }^{71}$

The principal test to determine when such delegations are illegitimate-the nondelegation doctrine-is a Lochner-era product that has not exerted much influence since $1935 .^{72}$ While minimum standards of delegability seem critical to maintaining a regime of separated powers, the courts nevertheless have found the vast majority of delegations of legislative authority to the Executive to be acceptable. ${ }^{73}$ Despite the fact that the nondelegation doctrine has lain dormant for nearly sixty years, however, there have been recent indications that

69. See United States v. Curtiss-Wright Export Corp., 299 U.S. 304 (1936). There, the Supreme Court upheld Congress's delegation of the power to prohibit the export of arms to certain foreign nations, finding that such delegation of discretionary authority was consistent with the President's presumed authority in foreign affairs. The Court noted "the unwisdom of requiring Congress in this field of governmental power to lay down narrowly defined standards by which the President is to be governed." Id. at 321-22. Other decisions relying on a Curtiss-Wright theory of generalized deference to the President in foreign affairs include Regan v. Wald, 468 U.S. 222 (1984) (upholding President's power to block travel to Cuba); Haig v. Agee, 453 U.S. 280, 291 (1981) (reading vague statute broadly to uphold Secretary of State's revocation of passport); Zemel v. Rusk, 381 U.S. 1, 7 (1965) (granting President rule-making authority over issuing passports).

70. Curtiss-Wright, 299 U.S. at 320 ("[C]ongressional legislation which is to be made effective through negotiation and inquiry within the international field must often accord to the President a degree of discretion and freedom from statutory restriction which would be inadmissable were domestic affairs alone involved.").

71. Curtiss-Wright hardly precludes the possibility that significant portions of Congress's central Article I appropriations power cannot constitutionally be delegated. For instance, as Michael Glennon observes, "That an aspect of the foreign commerce power happens to be delegable says little or nothing about the delegability of central elements of the war power." MICHAEL J. GLENNON, CONSTITUTIONAL DIPLOMACY 201 (1990).

72. For general discussions of the nondelegation doctrine, see Peter H. Aranson et al., $A$ Theory of Legislative Delegation, 68 CORNELL L. REV. 1, 7-17 (1982) (reviewing judicial history of nondelegation doctrine and arguing for its revitalization); David Schoenbrod, The Delegation Doctrine: Could the Court Give it Substance? 83 MICH. L. REv. 1223 (1985); David Schoenbrod, Separation of Powers and the Powers That Be: The Constitutional Purposes of the Delegation Doctrine, 36 AM. U. L. REV. 355 (1987); Richard B. Stewart, Beyond Delegation Doctrine, 36 AM. U. L. REv. 323 (1987) (arguing that courts should not invoke nondelegation doctrine to invalidate congressional statutes).

73. In the last full-fledged application of the nondelegation doctrine, A.L.A. Schechter Poultry Co. v. United States, 295 U.S. 495 (1935), the Supreme Court struck down a provision of the National Industrial Relations Act allowing the President to approve industrial codes set up by trade and industrial associations. The Court held that "Congress cannot delegate legislative power to the President to exercise an unfettered discretion to make whatever laws he thinks may be needed or advisable for the rehabilitation and expansion of trade or industry." Id. at 537-38. 
it is ripe for renewal. ${ }^{74}$ In South Dakota v. United States Department of the Interior, the Eighth Circuit recently employed the nondelegation doctrine to strike down a federal statute on the grounds that it provided the executive branch with unguided discretion to purchase public land or property on behalf of Native Americans. ${ }^{75}$ Additionally, two Supreme Court cases, Mistretta v. United States ${ }^{76}$ and Touby v. United States, ${ }^{77}$ signaled the Court's possible willingness to revive the nondelegation doctrine when Congress fails to provide an "intelligible principle" or a clear standard to the party exercising delegated power. $^{78}$ If such a renewal is to happen, it is hard to imagine a better object of its application than the presidential exercise of Congress's power of the purse. The spending power is central to Congress's constitutional function, and as the Court noted in Panama Refining Co. v. Ryan," " $[\mathrm{t}]$ he Congress manifestly is not permitted to abdicate, or to transfer to others, the essential legislative functions with which it is thus vested." 80

The intelligible-principles test articulated in Mistretta and Touby and employed in South Dakota ensures that Congress does not abdicate essential

74. See Lisa A. Cahill \& J. Russell Jackson, Note, Nondelegation After Mistretta: Phoenix or Phaethon?, 31 WM. \& MARY L. REV. 1047, 1081-95 (1990) (arguing that nondelegation doctrine should be revived).

75. South Dakota v. United States Dep't of the Interior, 69 F.3d 878 (8th Cir. 1995). The majority found "no perceptible 'boundaries,' no 'intelligible principles,' within the four corners of the statutory language that constrain this delegated authority-except that the acquisition must be "for Indians,"' and held that the bill "delegates unrestricted power to acquire land from private citizens for the private use and benefit of Indian tribes or individual Indians." Id. at 882.

76. Mistretta, 488 U.S. 361 (1989) (finding that delegation of authority to promulgate sentencing guidelines to independent sentencing commission does not violate nondelegation doctrine).

77. 500 U.S. 160 (1991) (finding that delegation of power to designate new drugs as schedule I controlled substances does not violate nondelegation doctrine since Congress had supplied Attorney General with adequate instructions).

78. 488 U.S. at 371-89 (applying intelligible-principles test to sentencing guidelines and holding that guidelines meet such standard). The principle that congressional delegations of legislative power must be governed by "intelligible standards" was set forth in Hampton \& Co. v. United States, 276 U.S. 394 (1928). Holding that a provision of the Tariff Act of 1922, which created a rate-making commission to set tariff schedules, did not unconstitutionally delegate the legislative rate-making power, the Court noted that "[i]f Congress shall lay down by legislative act an intelligible principle to which the person or body authorized to fix such rates is directed to conform, such legislative action is not a forbidden delegation of legislative power." Id. at 409. The necessary analogue to this position, of course, is that if Congress fails to lay down an intelligible principle for executive implementation, an unconstitutional delegation of legislative power has occurred. In NBC v. United States, 319 U.S. 190, 225-26 (1943), the Court applied such a test to uphold the power of the FCC to promulgate regulations in accordance with the "public interest." One year later, the court applied an even more comprehensive "absence of standards" test in order to weigh the constitutionality of the delegation to a price administrator of the power to fix commodity prices.

"Only if we could say that there is an absence of standards for the guidance of the

Administrator's action, so that it would be impossible in a proper proceeding to ascertain whether the will of Congress has been obeyed, would we be justified in overriding its choice of means for effecting its declared purpose...."

Mistretta, 488 U.S. at 379 (quoting Yakus v. United States, 321 U.S. 414, 426 (1944)).

79. 293 U.S. 388 (1935).

80. Id. at 421. Accordingly, the Panama Refining Court struck down a provision of the National Industrial Recovery Act that allowed the President to prohibit the interstate transportation of oil produced in surplus of amounts fixed by state law. The Court reasoned that in passing the Act, "the Congress ha[d] declared no policy, ha[d] established no standard, ha[d] laid down no rule." Id. at 430 . The effect, the Court concluded, was "to invest [the President] with an uncontrolled legislative power." Id. at 432. 
legislative functions, by requiring that the space separating the legislative and executive powers remains clearly bounded. According to this principle, the executive branch cannot exercise discretion unless it does so in accordance with clear instructions-intelligible principles-provided by Congress.

Comparing the use of the ESF to bail out Mexico with the circumstances of Mistretta and Touby, in which the Court did find that Congress had supplied sufficient intelligible principles, is instructive. In Mistretta, the Court refused to strike down Congress's delegation of authority to draft new sentencing guidelines to an independent commission. In so doing, the Court noted extensive and highly detailed instructions under which the commission was required to operate. ${ }^{81}$ In Touby, the Court approved Congress's delegation to the Attorney General of the discretion to declare new drugs to be controlled substances and the Attorney General's subsequent delegation to the Drug Enforcement Agency (DEA) of the authority "to schedule controlled substances on a temporary basis." ${ }^{\text {82 }}$ Although the Court indicated that the statutory instruction provided by Congress to schedule drugs presenting "imminent hazard to the public safety" satisfied the intelligible-principles test, it proceeded to identify an extensive list of standards provided by Congress to guide the Attorney General's discretionary authority. ${ }^{83}$

Since exercising the power of the purse is a legislative function assigned to Congress by the Constitution, the nondelegation doctrine implies that the executive branch cannot spend money in the absence of congressionally supplied principles regarding its use, except for those purposes explicitly reserved to the executive branch in Article II. In contrast to the delegations found acceptable in Mistretta and Touby, if $\S 5032$ allows ESF resources to be used for foreign bailouts, it provides no criteria or guidance, beyond indicating the Secretary's discretion to use Fund resources. Certainly, no guidelines govern the President's access to the funds that are at all comparable in specificity to those noted by the Court in Mistretta and Touby.

The intelligible-principles test requires particularly vigilant application to revolving funds like the ESF since the transfer of such funds to the executive branch threatens to undermine Congress's appropriations authority. Common sense suggests that the larger the fund, the greater the need for clear standards regarding its use. When used as a tool of American foreign policy and a mechanism to deliver foreign aid, the $\$ 30+$ billion ESF exceeds the limits

81. The Court noted that Congress had provided three broad goals and four "purposes" of sentencing that the commission must pursue in exercising its discretion. Congress further provided substantial detail regarding the constraints available, the forms such guidelines must take, and the methods the commission should employ. See Mistretta, 488 U.S. at 374-75.

82. 500 U.S. at 164.

83. These instructions included the requirement that the Attorney General find that a drug "'has a high potential for abuse,' that it 'has no currently accepted medical use in treatment in the United States,' and that "[t]here is a lack of accepted safety for use of the drug . . . under medical supervision." Id. at 167 (quoting 21 U.S.C. $\$ 812(b)(1)$ ). 
imposed by the nondelegation doctrine. Thus even if the legality of the President's actions in the Mexican bailout remains unchallenged, the lack of intelligible standards governing ESF use make future struggles over its deployment inevitable, and the statute itself unconstitutional.

\section{B. Inherent Powers in the Zone of Twilight and Beyond}

The courts employ a rule of statutory construction mandating that where multiple interpretations of a statute are possible, the preferred reading is that which is consistent with the Constitution. ${ }^{84}$ Since a zone-one reading of $\$ 5302$ violates the nondelegation doctrine, the statute clearly should not be read to authorize the bailout. The bailout then must be analyzed under either zone two or zone three.

In many ways, Jackson's second zone, the "zone of twilight," best captures the legal ambiguity in which President Clinton executed the bailout. The legislative history of $\S 5302$, the actions and statements of Treasury and Federal Reserve Board officials up until just days before the Mexican package was announced, and the plain language of the statute itself all indicate that $\$ 5302$ was not designed, and Congress never intended, to give the President authority to extend large aid packages to foreign nations without explicit congressional authorization. A legislative package had been sent to Congress, but congressional deliberations had produced neither a grant nor a denial of authority, and, in the face of what can fairly be described as "congressional inertia," the President decided that economic circumstances would not allow the deliberations process to run its course. The administration thus contended that the President's power to draw on a hazily circumscribed fund, for purposes not entirely at odds with the apparent purposes of the Fund, is concurrent with Congress's power to control its use, and that congressional inaction in the face of a national security crisis should be read as tacit authorization of presidential management of the crisis. ${ }^{85}$ By this argument, barring the passage of actual legislation prohibiting the Mexican bailout, the bailout should be considered to have been authorized.

The Supreme Court adopted such a view of congressional acquiescence in Dames \& Moore $v$. Regan, ${ }^{86}$ in which it considered the constitutional

84. See, e.g., Edward J. DeBartolo Corp. v. Florida Gulf Coast Bldg. \& Constr. Trades Council, 485 U.S. 568, 574 (1988).

85. The Court has at times interpreted legislative acquiescence as constituting consent. See, e.g., Haig v. Agee, 453 U.S. 280, 290-92 (1981) (upholding Secretary of State's broad authority to revoke passport despite lack of explicit congressional authorization, since "in the areas of foreign policy and national security . . . congressional silence is not to be equated with congressional disapproval"). But see Lee R. Marks \& John C. Grabow, The President's Foreign Economic Powers After Dames \& Moore v. Regan: Legislation by Acquiescence, 68 CORNELL L. REV. 68, 85-87 (1982) (refuting Court's reading of Haig v. Agee to support conclusion that legislative acquiescence constituted consent).

86. 453 U.S. 654 (1981). 
authority of the President to nullify attachments on Iranian assets frozen by executive order. Following the taking of American hostages by militant Iranian students in 1979, President Carter ordered all Iranian assets in the United States frozen. ${ }^{87}$ American litigants pressing claims against Iran subsequently attached billions of dollars of Iranian assets. When a deal providing for the release of the hostages was finally negotiated, Iran's assets were unfrozen by executive order and sent abroad, with a portion placed in a trust account. All attachments on Iranian assets were dissolved, and jurisdiction over the claims was transferred to a special claims tribunal. ${ }^{88}$ The Supreme Court examined the statutory provisions relating to the settlement of foreign claims and found no direct authorization for the President's actions. ${ }^{89}$ In upholding the action, however, it found that the President's actions were "consistent" with other statutory powers provided the President and that there was a history of executive action in this field. ${ }^{90}$ These facts, combined with Congress's acquiescence in the settlement, ${ }^{91}$ provided the President with the authority to dissolve Dames \& Moore's attachments. Despite the lack of statutory authority, Congress's refusal to reverse presidential action, taken in zone two, was held to be sufficient to indicate authorization.

The approval of broad executive authority in Dames \& Moore allowed the President to resolve the Iranian hostage crisis-a foreign relations debacle-without being embarrassed by the judicial branch. But this approach to separation of powers is unsatisfactory principally for the reason that it endows the President with extraordinary powers to make policy normally reserved to Congress and seriously infringes upon Congress's practical ability to exert its authority when a dispute arises with the executive branch. ${ }^{92}$ By shifting the policymaking initiative to the executive, this approach raises the threshold for congressional action from a simple majority vote to the much more demanding two-thirds majority necessitated by the likelihood of a presidential veto. The assumption that the President retains an inherent power to make policy in "zone of twilight" disputes, therefore, seriously undermines congressional authority. ${ }^{93}$

\footnotetext{
87. Id. at $662-63$.

88. Id. at $665-66$.

89. Id. at 678 .

90. Id. at 686 .

91. Id. at 687.

92. The Court itself strenuously tried to limit Dames \& Moore's holding to its facts. See id. at 688 .

93. See Erwin Chemerinsky, Controlling Inherent Presidential Power: Providing a Framework for Judicial Review, 56 S. CAL. L. REV. 863, 889 (1983). One solution to this problem would be to modify the strict ban on legislative vetoes established in INS v. Chadha, 462 U.S. 919 (1983), to the extent that the ban prevents Congress from overriding disfavored presidential acts of lawmaking. See Abner $\mathrm{S}$. Greene, Checks and Balances in an Era of Presidential Lawmaking, 61 U. CHI. L. REV. 123, 126 (1994) (arguing for constitutionality of concurrent resolutions adopted to block executive acts of lawmaking). At minimum, Congress has a strong incentive to articulate its preferences clearly by framing legislation so that "zone of twilight" conflicts arise infrequently. Certainly, the authorizing language of the ESF does not provide such articulation.
} 
Furthermore, given that the Court's approval of presidential authority ultimately hinged on a finding, as Justice Frankfurter described in Youngstown, that Congress had ceded the relevant field of action to the President, Dames \& Moore can only provide constitutional precedent for the bailout upon a showing that the President has traditionally claimed jurisdiction in the area of foreign bailouts. ${ }^{94}$ But, as noted above, ${ }^{95}$ no systematic, unbroken administrative practice of using the ESF for foreign bailouts exists. Therefore, in order for the President to claim authorization for the bailout, he must show that the provision of foreign aid is inherent in his broader Article II powers, since authorization under either zone two or three requires the President to identify an independent constitutional basis for his actions.

\section{The Provision of Foreign Aid Is Not an Inherent Article II Power}

The strongest precedent for the existence of inherent and sweeping presidential foreign affairs powers is United States v. Curtiss-Wright Export Corp. ${ }^{96}$ In famous dicta, Justice Sutherland asserted that the President holds an exclusive power as "the sole organ of the federal government in the field of international relations-a power which does not require as a basis for its exercise an act of Congress." Wright that the President's foreign affairs power "of course, like every other governmental power, must be exercised in subordination to the applicable provisions of the Constitution." 98

The Constitution unambiguously assigns the power to make appropriations to Congress. Article I provides that "No money shall be drawn from the Treasury, but in consequence of appropriations made by law." viewed Congress's exclusive power to appropriate as a vital tool in the congressional arsenal and as an important improvement over the British system, in which the appropriations power was ambiguously divided between the King and Parliament, and much of the King's revenues came from extraparliamentary sources. ${ }^{100}$ Like the power to declare war, Congress's power to appropriate funds was "specially intended in the United States as an

94. See Youngstown Sheet and Tube Co. v. Sawyer, 343 U.S. 579, 610-11 (1952).

95. See supra Section I.C.

96. 299 U.S. 304 (1936) (finding that President's foreign relations power derives not from Constitution, but directly from nature of sovereignty).

97. Id. at 320.

98. Id. That those requirements strongly limit the President's power to make laws was emphasized in Youngstown. "[T]he President's power to see that the laws are faithfully executed refutes the idea that he is to be a lawmaker. The Constitution limits his functions in the lawmaking process to the recommending of laws he thinks wise and the vetoing of laws he thinks bad." Youngstown, 343 U.S. at 587. For a discussion of the ways the Court has interpreted Curtiss-Wright and Youngstown, see HAROLD HoNGJU KOH, THE NATIONAL SECURITY CONSTITUTION 134-46 (1990).

99. U.S. CoNST. art. I, \& 9, cl. 7.

100. See Peter Raven-Hansen \& William C. Banks, Pulling the Purse Strings of the Commander in Chief, 80 VA. L. Rev, 833, 891 (1994). 
antidote to executive abuse of military power and as a tool for congressional control of such power."101 Given this purpose and the abundant tools available to the executive branch to pursue its goals, it would be difficult to overstate the centrality of Congress's exclusive appropriations power in the scheme of separated powers. As Edward Corwin noted, the power of the purse is "the most important single curb in the Constitution on Presidential power." 102

Congress's exclusive power to appropriate has been regularly affirmed, ${ }^{103}$ even in areas involving foreign affairs. For instance, in Edwards $v$. Carter, the D.C. Circuit noted that "[ $t]$ he expenditure of funds by the United States cannot be accomplished by self-executing treaty; implementing legislation appropriating such funds is indispensable."104 Congress has frequently used its appropriations power to limit executive discretion in foreign affairs. ${ }^{105}$ When Congress seeks to assert its policymaking authority in foreign matters, it "is on firmest constitutional ground when it deploys its undoubted discretion over government spending." 106 Congress would be helpless to so limit executive discretion if the President had an independent power to appropriate funds.

Accordingly, it would seem that the President's appropriations power can be summed up in a word: nonexistent. Professor Kate Stith has called this the "Principle of Appropriations Control," under which "expenditure of any public money without legislative authorization" is constitutionally prohibited. ${ }^{107}$ The

101. Id. at 890 .

102. EdWARd S. CoRWIN, The Constitution and What IT Means Today 101 (13th ed. 1975).

103. See, e.g., Cincinnati Soap Co. v. United States, 301 U.S. 308, 321 (1937) (holding that Appropriations Clause was "intended as a restriction on the disbursement authority of the Executive department, and ... means simply that no money can be paid out of the Treasury unless it has been appropriated by an act of Congress"); Knote v. United States, 95 U.S. 149, 154 (1877) (noting that President "cannot touch moneys in the treasury of the United States, except expressly authorized by act of Congress"); Reeside v. Walker, 52 U.S. (11 How.) 272, 291 (1850) (same).

104. 580 F.2d 1055, 1058 (D.C. Cir. 1978) (rejecting challenge of coalition of Congresspersons to treaty negotiated by President Carter and ratified by Senate transferring ownership of Panama Canal to Panama, because President retains power to dispose of U.S. property through treaty-making power, but noting in dicta that appropriations power can never be exercised without full participation of Congress).

105. For an overview of congressional restrictions on foreign assistance, see Jeffrey A. Meyer, Congressional Control of Foreign Assistance, 13 YALE J. INT'L L. 69 (1988). Such restrictions include congressional oversight of arms sales, and restrictions on assistance to regimes violating basic norms of human rights and regimes disproportionately responsible for illegal drug production. Id. at 73-96.

106. Thomas M. Franck \& Clifford A. Bob, The Return of Humpty-Dumpty: Foreign Relations Law After the Chadha Case, 79 AM. J. INT'L L. 912, 944 (1985). According to Michael Glennon, "The Supreme Court has never held unconstitutional any use of the appropriations power to limit the exercise of power by the executive branch." Michael J. Glennon, Strengthening the War Powers Resolution: The Case for Purse-Strings Restrictions, 60 MiNN. L. REv. 1, 29 (1975).

107. Kate Stith, Congress' Power of the Purse, 97 YALE L.J. 1343, 1345 (1988). Executive branch discretion over the spending power is already sharply limited by statute. Executive branch officials are statutorily prohibited by the Anti-Deficiency Act from spending funds that have not been specifically appropriated by Congress for such purpose. See 31 U.S.C. $\$ 1341$ (1994). Violators of the law are subject to criminal penalties. Id. $\S 1350$. Likewise, following a constitutional struggle with President Nixon over the President's refusal to spend monies that had been appropriated by Congress, Congress passed the 
principle, Stith asserts, extends to any and all activities engaged in by the Executive, even those that the Constitution has reserved to the executive branch alone. If the principle is applied to the Mexican crisis, it is clear that under either a Youngstown zone-two or zone-three analysis, the President had no independent authority to initiate the bailout since he simply " cannot spend money on his own authority for foreign aid." 108

Critics of Stith's principle, however, argue that Congress's control of the purse should not endow it with an effective veto over all executive branch action, especially over those powers granted directly by the Constitution. ${ }^{109}$ Applied coercively to restrict authentic Article II presidential authority, ${ }^{110}$ the appropriations power may be misused. Still, Congress's failure to exercise its appropriations power in a constitutionally acceptable way does not thereby create an independent power in the executive branch to assume legislative functions. " The two propositions are logically discrete. ${ }^{112}$

Even if the President has a strong constitutional interest in one area, as he does in foreign affairs, he may lack the constitutional means to intercede

Congressional Budget and Impoundment Control Act of 1974, making such executive branch behavior illegal. Ch. 17A, 88 Stat. 298 (1974) (codified as amended at 2 U.S.C. $\$ \$ 621-688$ (1994)).

108. Edwards, 580 F.2d at 1069 (MacKinnon, J., dissenting) (quoting Louls HeNKIN, FoREIGN AFFAIRS AND THE CONSTITUTION 94-96 (1972)).

109. Notes Gregory Sidak: "This theory encompasses far more than fiscal responsibility; it envisions the appropriations power as an omnipresent legislative veto on presidential action." J. Gregory Sidak, The President's Power of the Purse, 1989 DUKE L.J. 1162, 1162. As Sidak points out, by withholding appropriations, Congress should not be able to prevent the President from carrying out constitutional duties. For instance, because the Presentment Clause, U.S. CONST. art. I, § 7, cl. 2, ensures that no bill can become law without presentment for a presidential signature, Congress could not refuse to appropriate money for pens in order to prevent the President from exercising his constitutional duty to sign legislation.

110. Scholars have heatedly debated the definition of "authentic" Article II powers. While Professor Stith views the category of authentic Article II duties as relatively narrow, Sidak considers it to be much more expansive:

The performance of the President's duties and prerogatives under article II can be viewed as different kinds of public goods-enforcing the law, negotiating treaties, sending and receiving ambassadors, commanding the armed forces, making recommendations to Congress, issuing pardons, and so forth. . . . If Ronald Reagan honestly believed that deployment of the Strategic Defense Initiative were 'minimally necessary' to defend the United States from nuclear attack by the Soviet Union, could he have encumbered the Treasury for billions of dollars?

Sidak, supra note 109, at 1197. Sidak indicates that he finds this proposition at least less than "preposterous." Id.

II1. It may, however, be a form of "coercive deficiency." See 59 Comptroller General 369 (1980) (defining "coercive deficiencies" as those commitments for which "Congress has little choice but to appropriate the necessary funds"); $6 \mathrm{Op}$. Att'y Gen. 27 (1853) (concluding that where President had made contract entailing expenditures for which Congress had not appropriated monies, a limitation arose, but such limitation did not constrain the President's authority to contract, only "his power to bind the United States, beyond the amount appropriated by Congress").

112. Critics of this argument may respond that any congressional failure to appropriate necessary funds creates a problem of enforcement. Who will ensure that Congress's breach is remedied? The courts? Does this then provide the courts with implied appropriations powers? The answer is no. There is no guarantee that all unconstitutional acts can be remedied. Also, ordering performance based on judicial interpretation of the Constitution does not endow the courts with those powers any more than a judge's order to a delinquent husband to pay alimony endows that judge with the power to levy a tax. 
without congressional assistance. ${ }^{113}$ The unambiguous constitutional assignment of the appropriations power to Congress ${ }^{114}$ and the historical absence of any comparable precedent for executive-branch-initiated bailouts indicate that any "bailout powers" belong to Congress, not the President.

Further, while the lack of formal congressional resistance signifies that the bailout did not violate the express will of Congress, the bailout nonetheless may have violated Congress's implied will. When the administration announced it was replacing the legislative aid package under congressional consideration with a bailout package not requiring legislative approval, it was widely believed that the legislative proposal would not in any case have been passed by Congress. ${ }^{115}$ In Youngstown, the Court read a great deal into the fact of legislative inaction when proposals for action were considered. Supporting the finding that President Truman's seizure of the nation's steel mills was unauthorized, Justice Black pointed out that, four years earlier, Congress had considered and "rejected an amendment which would have authorized such governmental seizures in cases of emergency."116 As Frankfurter explained:

It is quite impossible, however, when Congress did specifically address itself to a problem, as Congress did to that of seizure, to find secreted in the interstices of legislation the very grant of power which Congress consciously withheld. To find authority so explicitly withheld is not merely to disregard in a particular instance the clear will of Congress. It is to disrespect the whole legislative process and the constitutional division of authority between President and Congress. ${ }^{117}$

Youngstown thus established the proposition that Congress may speak by not speaking, that a failure to pass authorizing language can constitute a clear statement of purpose. Since it appeared likely that Congress would not approve the originally proposed package of loan guarantees, the President arguably acted in the face of an implicit denial of authorization to provide any aid to

113. In war powers, for instance, though the Commander in Chief Clause gives the President constitutional power to command military forces, Congress must first raise and support military forces before the President can exercise that command. See U.S. CoNST. art. I, \$ 8, cl. 12.

114. According to Glennon, the appropriations power is "an unquestionably exclusive congressional power." Glennon, supra note 106 , at 32.

115. See Susan Cornwell, Gingrich Wary as Clinton Pushes Plan to Buoy Peso, CHI. SUN-Times, Jan. 31,1995 , at 8 (reporting that Mexico's main stock market index plunged "as pessimistic investors seemed to bet on defeat for the loan guarantees"); Major Garrett \& Joyce Price, GOP Bill Would Outlaw Clinton's Mexico Plan, WASH. TIMES, Feb. 3,1995 , at A8 (noting that the $\$ 40$ billion package of loan guarantees had been "[f]acing certain defeat").

116. Youngstown Sheet and Tube Co. v. Sawyer, 343 U.S. 579, 586 (1952). The Court was referring to congressional debate over labor disputes affecting national security during consideration of the TaftHartley Act, 61 Stat. 136, 152-56 (1947) (codified as amended at 29 U.S.C. \$ 141 (1994)).

117. Youngstown, 343 U.S. at 609 (Frankfurter, J., concurring). 
Mexico. The President's authority to extend the bailout package unilaterally was thus "at its lowest ebb."

Under any configuration of statutory and constitutional analysis, then, the President lacked the means to carry out the bailout. But such a finding is constitutionally problematic if, as I argue in the following part, the economic effects of the Mexican crisis were sufficiently severe to be considered a threat to national security. The President's constitutional authority to protect national security may thus provide the Executive with concurrent authority, a finding that firmly mires analysis of the bailout in the "zone of twilight."

\section{National ECONOMIC Security AND the Power of the PURSE}

\section{A. National Security in an Era of Global Markets}

Historically, national security has been described in military or geostrategic terms. ${ }^{118}$ If the Mexican bailout-which did not involve any clear military aspects-was necessitated by national security, as the administration vigorously argued, ${ }^{119}$ a more expansive definition of the concept is required. Developments in modern financial and economic technologies may warrant such a redefinition. ${ }^{120}$ As Helmut Schmidt pointed out in 1977, events during the mid-1970s, such as the oil crisis, worldwide inflation, and monetary instability, revealed the importance of the "economic dimension of national security."'121 In an era characterized by unprecedented economic interdependence, it is increasingly imperative that definitions of national security include threats to a nation's "economic security." 22

118. For a general discussion of the history of U.S. national security policy, see AMOS A. JORDAN ET AL., AMERICAN NATIONAL SECuRITY (4th ed. 1993).

119. In testimony before the Senate Banking Committee, Secretary Rubin asserted that "President Clinton acted to avert a crisis" threatening "national interests," and that "[t]hese dangers to our interests reached beyond Mexico with the potential for spill-over effects in other developing countries around the world where we have strong economic interests and strong national security interests." Mexican Peso Crisis, supra note 1, at 355 (statement of Robert Rubin, Secretary of the Treasury).

120. The introduction of new technologies has led to increased interdependence in global markets. As one commentator notes, "The recent introduction of automated screen-driven technology is beginning to threaten the market's local exchange infrastructure and to transform the way this evolving marketplace will function in the future." Peter E. Millspaugh, Global Securities Trading: The Question of a Watchdog, 26 GEO. WASH. J. INT'L L. \& ECON. 355, 361-62 (1992). This interdependence can lead to significant threats on a larger scale. One nation's default may trigger a worldwide chain reaction.

If as a result of country debt defaults one or more of the larger banks active in the Eurocurrency

market cannot meet its repayment obligations on interbank loans, the banks of other countries

will in tum have to default on their loans. ... Will the central banks acting together and with

the help of the international financial institutions be able to act fast enough to avert a calamity?

ThiBAut dE SAINT PHALle, THE FEDERAL RESERVE: AN INTENTIONAL MYSTERY 274 (1985).

121. JOSEPH J. ROMM, Defining National SECURITY: THE NONMILITARY ASPECTS 54 (I993) (quoting Helmut Schmidt, The 1977 Alastair Buchan Memorial Lecture (Oct. 28, 1977)). To Schmidt, this meant "the necessity to safeguard free trade access to energy supplies and to raw materials, and the need for a monetary system which will help us to reach those targets." Id.

122. For a discussion of these new vulnerabilities, see generally THE CHALLENGE OF INFORMATION TECHNOLOGY FOR THE SECURITIES MARKETS: LIQUIDITY, VOLATILITY, AND GLOBAL TRADING (HenIy C. 
The foreign policy establishment has embraced the concept of "economic security," if somewhat haltingly. ${ }^{123}$ Certainly, policymakers have always recognized the highly salient relationship between uninterrupted access to resources like uranium and oil and the protection of national security. An extensive literature exists evaluating the ways that economic sanctions can be deployed to achieve essentially military purposes. ${ }^{124}$ Passage of the Trading With the Enemy Act (TWEA) ${ }^{125}$ in 1917, and its successor statute, the International Emergency Economic Powers Act (IEEPA), ${ }^{126}$ in 1977, represents Congress's longstanding recognition that the President must have the authority to exercise economic regulatory powers in order to facilitate his Commander in Chief powers in the handling of economic crises. ${ }^{127}$

Lucas \& Robert A Schwartz eds., 1989); Timothy A. Canova, The Transformation of U.S. Banking and Finance: From Regulated Competition to Free-Market Receivership, 60 BROOK. L. REV. 1295, 1351-52 (1995) (" $[T]$ he liberalization of international capital flows has created a world in which the sovereignty of any one nation is surrendered to the forces of private financial speculation."); Roy C. Smith, Risk and Volatility, WASH. Q., Autumn 1995, at 117 (evaluating costs and benefits of regulation of market volatility).

123. The creation of the National Economic Council (NEC), an economic counterpart to the National Security Council, is only the most prominent symbol of this new recognition. See William Safire, Who's Got Clout, N.Y. TIMES, June 20,1993, § 6 (Magazine), at 25 (describing NEC as a "new power center . . created to show the public that in the new era, economic policy would be at least as high a priority as national security"). Frequently, discussions of "economic security" focus on ways that economic tools can be used to coerce enemies or rivals, or conversely, ways that military conflict can be transferred to economic arenas. But there are clear dangers to equating international economic competition with military combat, as do many commentators concerned with the rise of the Japanese economy. As one scholar points out, "by stressing threats to national interests in the international arena, an emphasis on economic security could incorrectly stress coercion against economic competitors rather than domestic policies to enhance competitiveness." JamES R. GOLDEN, ECONOMICS AND NATIONAL STRATEGY IN THE INForMation AgE 7 (1994). Conceptualizing the protection of the world monetary and financial system as an issue of national security must avoid this pitfall. In this regard, "economic security" should resemble the attempts by persons concerned with environmental issues to reformulate them in terms of national security. Advocates of "environmental security" see nothing contradictory about security measures that are by their very nature cooperative, inclusive, and global in scope. See, e.g., MICHAEL RENNER, NATIONAL SECURITY: THE ECONOMIC AND ENVIRONMENTAL DimEnsions 64 (Worldwatch Paper No. 89, May 1989) (arguing that “"national security' as such has become an outmoded concept: security is increasingly attained through the difficult process of global cooperation to create mechanisms for nonviolent dispute settlement and establish environmental alliances").

124. See, e.g., Barry E. Carter, International Economic Sanctions: Improving the Haphazard United States Legal Regime, 75 CAL. L. REV. 1162 (1987) (discussing use of economic sanctions generally); Koh \& Yoo, supra note 13, at 715-16 (discussing "laws that manipulate fiscal, monetary, and domestic economic policies to achieve national security goals" and "laws that control or respond to external relations through economic measures").

125. 40 Stat. 411 (1917) (codified as amended at 50 U.S.C. app. $\$ \$ 1-44$ (1988)); H.R. REP. No. 85, 65th Cong., 1st Sess. 1 (1917).

126. 91 Stat. 1626 (1977) (codified as amended at 50 U.S.C. $\$ \$ 1701-1706$ (1988)).

127. The IEEPA does not provide any mechanism for funding presidential initiatives taken under the IEEPA's authority. However, the National Emergencies Act includes a provision requiring that, after the President declares a state of emergency, he is obligated periodically to transmit to Congress "a report on the total expenditures incurred by the United States Government . . . which are directly attributable to the exercise of powers and authorities conferted by such declaration." 50 U.S.C. \$ 1641(c) (1988). 


\section{B. Evaluating Threats to Economic Security}

As the administration vigorously argued, in a world of highly interdependent financial markets, repercussions from the collapse of a large national economy like Mexico's might instantaneously spread through U.S. domestic markets to harm interests extending far beyond direct investors. To determine when the consequences of such a collapse are broad enough in scope to constitute a threat to national security, policymakers should examine its potential effect on three principal institutions: the currency, the national banking system, and financial markets. A fourth possible object of protection - the investments of discrete international investors-should be rejected as a justification for presidential action under the rubric of national security since losses suffered by such investors, absent unusual circumstances, do not threaten the broader welfare. Finally, presidential spending in response to financial crises may be justifiable even for purposes traditionally viewed as part of the legislative domain when intense time pressures make careful deliberation by Congress impossible.

\section{Protection of the Currency}

The ESF was originally established to protect the exchange value of the dollar, and it remains a primary tool to guard against sudden shifts in currency value. Though exchange rates ultimately are determined by fundamental economic factors and long-term policy choices, short-term fluctuations in exchange rates can have detrimental consequences on import-export balances, and they can create volatility damaging to the national economy.

\section{Protection of the National Banking System}

Though maintenance of a healthy banking system ultimately depends on wise regulatory policy and thus on Congress's ability to formulate such policy, ${ }^{128}$ the leveraging of capital assets and their wide distribution throughout the entire financial system mean that some economic catastrophes threaten the entire system. The executive branch traditionally has claimed and exercised power to prevent systemic failure. ${ }^{129}$ Given the centrality of the

128. See Canova, supra note 122, at 1353 (discussing history of banking and finance policy and new regulatory paradigm of private speculation); James F. Groth, Comment, Can Regulators Force Bank Holding Companies to Bail Out Their Failing Subsidiaries?-An Analysis of the Federal Reserve Board's Source-of-Strength Doctrine, 86 Nw. U. L. REV. 112, 135 (1991) (noting recognition among lawmakers and regulators that "banking industry requires special regulatory attention").

129. President Roosevelt's declaration of a bank holiday as a response to the growing bank panic at the height of the great depression provides one such example. See Proclamation No. 2039, 48 Stat. 1689 (1933) (temporarily suspending all banking transactions); Proclamation No. 2040, 48 Stat. 1691 (1933) 
banking system to the economic viability of the nation, foreign threats to it must therefore remain a significant concern of the executive branch.

\section{Protection of Financial Markets}

The collapse of financial markets may have devastating effects, particularly in the short term, on the health of the national economy as a whole. Though stock market crashes are sometimes said to result only in "paper losses,"130 the resulting decrease in asset value can set off a chain reaction leading quickly to real economic contraction. ${ }^{131}$ The interconnection of various kinds of market-determined valuations means that the decrease in one market can set off a chain of consequences ultimately threatening the entire economy.

\section{The Protection of Discrete Financial Interests}

The executive branch often takes emergency action intended to protect the financial interests of particular investors. The threatened nationalization of U.S. companies, for instance, has on occasion sparked intense executive branch response, up to and including fomenting revolutions. ${ }^{132}$ Foreign economic crises-particularly defaults-will almost always threaten the financial position of discrete interests. It is far from clear, however, that the threat to those interests raises legitimate national security concerns. Unless the threat touches upon national welfare, intervention should be carried out according to congressional policy and traditional forms of executive branch diplomacy.

Where executive discretion concerns not a regulatory power, as in CurtissWright, but the spending power, decisions are especially likely to be made on grounds that favor particularly well-positioned or powerful interests. ${ }^{133}$ Indeed, underlying much of the persistent opposition to the bailout plan was the belief that the real beneficiaries of the bailout were U.S. investors and bondholders facing large losses due to peso devaluation or large-scale Mexican

(extending suspension). Statutory authority for the declaration was provided by the Trading With the Enemy Act, ch. 106, §5(b), 40 Stat. 411,415 (1917).

130. See, e.g., David E. Pitt, The Market Turmoil: A Far-Reaching Impact; Just a Paper Loss, the Richest Say, N.Y. TIMES, Oct. 21, 1987, at D14.

131. In the first four years following the 1929 stock market crash, "real income dropped by a whopping thirty-six percent," which in tum "dramatically impacted on banks." J. Michael Echevarria, $A$ Precedent Embalms a Principle: The Expansion of the D'Oench, Duhme Doctrine, 43 CATH. U. L. REV. 745,753 (1994).

132. For an analysis postulating that the overthrow of the Arbenz government in Guatemala was triggered in large part by the expropriation of land owned by the United Fruit Company, see WALTER LAFEBER, Inevitable Revolutions: The UNITED STATES IN CenTRAL AMERICA I11-25 (1984).

133. President Clinton vigorously denied that the bailout was effected for such reasons, arguing that it " is in the interest of America, contrary to what some have said, not because there are some large financial interests at stake, but because there are thousands of jobs and billions of dollars of American exports at stake."' William Schneider, The Populist Takeover of Congress, 27 NAT'L J. 394, 394 (1995). 
loan default. ${ }^{134}$ Moreover, Secretary Rubin's former ties to the investment banking firm of Goldman Sachs, a bank with significant interests in Mexican markets, cast doubt on the detachment with which he was able to evaluate the bailout. ${ }^{135}$ Even where no direct conflict-of-interest concerns are involved, the exercise of such vast appropriations authority, unchecked by the normal scrutiny of legislative debate, can lead to undemocratic results. ${ }^{136}$ The decision of who should bear the cost of Mexican financial collapse-a quintessentially political choice-clearly resides with Congress.

\section{Time Pressures and Executive Capacity}

A separate justification for executive branch action absent congressional authorization arises when time constraints make congressional action impractical. Because financial crises can materialize rapidly, often following sudden and unexpected events, the capacity to respond often belongs realistically only to the executive branch. In the protection of national security, it has been recognized that the executive branch is at times the only institutional actor capable of responding to crises with dispatch. ${ }^{137}$

The majority of justifications provided by the administration for treating the Mexican crisis as a threat to national security-decreases in exports, massive influxes of illegal aliens, and an increase in the drug trade-fall into this category. ${ }^{138}$ Since the Constitution explicitly assigns to Congress, not the

134. Opponents of the plan described the bailout package as "corporate socialism," Mexican Peso Crisis, supra note 1, at 290 (testimony of Ralph Nader), and "a hidden subsidy for Wall Street and Mexico's elite," id. at 269 (testimony of Christopher Whalen, Chief Financial Officer, Legal Research International). As Senator D'Amato asked in evaluating the bailout, "Haven't we simply taken the United States taxpayer and inserted him in place of the Tesobono holder . . . ?" Id. at 619.

135. According to the American Spectator, "[b]etween 1992 and 1994, Goldman Sachs was the largest underwriter of Mexican financial issues, with a total exposure of $\$ 5.17$ billion." Christopher Caldwell, The Economics of Bailing Out, AM. SPECTATOR, May 1995, at 40, 40. Rubin himself handled the Mexico account while with the bank. Though Rubin recused himself on matters relating to NAFTA, he refused to do so in the Mexican bailout. Id.

136. If nothing else, the dispensation of large amounts of money by the executive branch creates the impression that a small cadre of special interests are receiving favorable treatment and raises disturbing issues of class interest or preference.

137. As one member of Congress justified the bailout:

[A]s envisioned by our founding fathers, the Executive has a greater capacity to act with dispatch than the legislative branch in foreign policy matters. Not envisioned by our founding fathers, Congress has developed a reluctance to share accountability for controversial approaches. Hence the Executive was forced to step to the plate while Congress took to the bleachers.

Hearings Before the House Comm. on Banking, Feb. 9, 1995, supra note 2, at 285 (statement of Rep. James Leach).

138. The administration listed a wide range of goals to justify attaching the national security label to the Mexican bailout. These included protecting American jobs, stemming an increased flow of illegal immigrants across the U.S. border, maintaining political stability in a neighboring country, and encouraging "reform in emerging markets around the world." Joint Statement, supra note 9, at 155. In a speech to the nation's governors, President Clinton added to this list the "'spread of financial instability to other countries in our hemisphere"' and "the potential of a more serious narcotics trafficking problem." Schneider, supra note 133, at 394. Concern about the spread of financial instability is reminiscent of the Vietnam-era domino 
President, the power to regulate trade, immigration, and violations of international law, ${ }^{139}$ most of these threats fall well within the congressional sphere of concern. Nonetheless, the looming threat of Mexican default severely limited the time available for Congress to deliberate. Rather than allow Mexico to default while Congress continued its debate, the executive branch chose to take preemptive action. ${ }^{140}$ Such an exertion of executive authority, when an immediate threat to the national interest is apparent, is consistent with the President's constitutional authority to respond to crises and mirrors his authority to deploy troops without prior congressional approval. ${ }^{141}$

One of the largest problems with troop deployments lacking congressional authorization, however, is that they prevent a full debate over the real degree of threat posed by a military enemy. ${ }^{142}$ Similarly, the premature termination of congressional deliberation brought about by the administration's unilateral action in the Mexican crisis prevented any final congressional determination of the actual severity of the economic threat. It thus remains far from clear whether substantial economic security concerns were actually at issue in the Mexican bailout.

In sum, extraordinary executive action purporting to protect national economic security should be evaluated to determine whether the threat is significant in intensity and national in scope. In economic crises, such threats are those that pose a danger to the nation's fundamental economic systems, particularly its banks, markets, and currency. Additionally, even in areas traditionally reserved for legislative branch regulation, presidential action may be warranted if time constraints make congressional authorization impossible.

In no case, however, should an identified threat justify a wholesale usurpation of Congress's appropriations power. ${ }^{143}$ In order to safeguard a

theory justification for intervention, and the threat (real or imagined) of financial collapse spreading to neighboring countries continues to be invoked as a primary rationale for the bailout. Senator Christopher Dodd applauded the administration's decision to intervene, asserting that "[y]ou were looking at a domino effect, a tumbling effect here that could have dwarfed the Mexican situation." Mexican Peso Crisis, supra note 1 , at 615 .

139. See U.S. ConST. art. I, $\$ 8$, cl. $3,4,10$.

140. As Treasury Secretary Rubin testified, at the time the bailout package was announced "in our view, Mexico [was] a day or two or three away from default, which in turn would have had all sorts of ramifications." Mexican Peso Crisis, supra note 1, at 620 (testimony of Robert Rubin, Secretary of the Treasury).

141. War Powers Resolution, 50 U.S.C. $\S 1541$ (c) (1988) (providing that "[t]he constitutional powers of the President as Commander-in-Chief to introduce United States Armed Forces into hostilities .... are exercised ... pursuant to ... (c) a national emergency created by attack upon the United States, its territories or possessions, or its armed forces").

142. See, e.g., J. Gregory Sidak, To Declare War, 41 DUKE L.J. 27, 33 (1991) ("A declaration of war fulfills Congress's representative function because it is more immediately visible to the electorate, less susceptible to ambiguity and disagreement once it is made, and thus more conducive to effective monitoring of the performance of political actors.").

143. As Justice Frankfurter noted, "the fact that power exists in the Government does not vest it in the President." Youngstown Sheet \& Tube Co. v. Sawyer, 343 U.S. 579, 604 (1952) (Frankfurter, J., concurring). Frankfurter further noted that the "[a]bsence of authority in the President to deal with a crisis does not imply want of power in the Govemment." Id. at 603-04 (Frankfurter, J., concurring). 
constitutional regime of separated powers, it is imperative that Congress's power of the purse be protected even while providing the President with the ability to respond, when necessary, to legitimate threats to national economic security. Striking the appropriate balance between the constitutional prerogatives of Congress and the practical advantages of presidential action is a congressional task. As Justice Jackson stated in Youngstown, "Power to legislate for emergencies belongs in the hands of Congress, but only Congress itself can prevent power from slipping through its fingers."

\section{STRUCTURAL SOLUTIONS}

Policymakers concerned with the threat to the U.S. economy posed by international financial catastrophes like the Mexican crisis could pursue responses at either the international or the domestic level.

\section{A. International Institutional Reform}

International solutions to the problems created by highly volatile international financial systems would seem superior to strictly domestic ones. ${ }^{145}$ As the Mexican crisis demonstrates, the costs of bailout can be substantial. It is unfair to place the burden of maintaining the solvency of the world economy on the shoulders of individual nations. The international economy - and the monetary system that supports it-is a highly valuable public good enjoyed by all participants in the world market. Creating mechanisms financed by the world community for responding to malfunctions of that system spreads the costs more evenly. ${ }^{146}$ In addition, monetary and financial crises severely strain the international economy, and systemic breakdown threatens the prosperity of all. Few nations are capable or willing consistently to perform the role of "lender of last resort."147 As a result,

144. Id. at 675 (Jackson, J., concurring).

145. Some first steps toward creating an international facility to respond to crises like Mexico's were discussed by members during the 1995 meeting of the G-7 in Halifax, Canada. The conference produced a package of proposals for dealing with future international financial crises, informally known as the "Halifax Initiatives." See Mexican Peso Crisis, supra note 1, at 610 (testimony of Robert Rubin, Secretary of the Treasury); Paul Lewis, Rubin Says World Economy in 'a Pause', N.Y. TIMES, Oct. 4, 1995, at D3 (describing a "proposed $\$ 50$ billion emergency fund that the IMF will use to bail out emerging economies in difficulties").

146. Some of the most important solutions may not require any capital outlay. For instance, one of the key proposals for international reform concerns the establishment of strict national reporting requirements allowing investors to monitor the solvency of foreign investments. The resulting increase in "transparency" will allow private actors to steer capital away from troubled economies, and prevent governments from avoiding necessary reforms. See Lewis, supra note 145, at D3.

147. See, e.g., Robert Gilpin, The POLITICAL ECONOMY OF International Relations 65-92 (1987) (discussing systemic need for lender of last resort). This role is normally assumed by the system's "hegemon," a role the United States has played since World War II. However, with the relative decline of the U.S. economy, many scholars, including Gilpin, argue that international regimes must replace hegemonic leadership for the international financial system to remain stable. See generally ROBERT O. 
financial repairs that make economic sense in terms of protecting world prosperity may go undone if no nation is willing to bear the cost of repeatedly expending its own resources for the benefit of all. ${ }^{148}$

Furthermore, reliance solely on international mechanisms may be unwise. Just as international peacekeeping forces directed by the United Nations have not obviated the need for a strong national military, the economic interests of the United States and the world community may at times diverge. Protection of national economic security may require that the U.S. government preserve a unilateral policy mechanism available to it when multilateral devices are insufficient or unable to respond to international crises that threaten national economic interests.

\section{B. Domestic Initiatives: Protecting Congress and National Economic Security}

Because the power of the purse, like the power of the sword, is one of the constitutional prerogatives the Framers were particularly intent on keeping firmly in the hands of Congress, and because the spending power in times of crisis functions similarly to the military power, it is not unreasonable to suppose that the President's powers in international economic crises should approximate existing warmaking powers. The history of the war power and the rise of the "imperial presidency" indicate the powerful advantages of executive control in the national security domain, as well as the antidemocratic effects of such control. ${ }^{149} \mathrm{~A}$ brief consideration of the most ambitious attempt to create a framework to grant and control war powers-the War Powers Resolution-might therefore provide a useful starting point for a consideration of appropriations-powers problems.

\section{War Powers as a Model for Appropriations Powers}

. Though critics of varying ideological bents agree that the War Powers Resolution, as currently written, is deeply flawed, ${ }^{150}$ its underlying

KEOHANE, AFTER HEGEMONY (1984) (arguing that new institutional regimes must be created to replace hegemonic leadership in order to maintain international cooperation).

148. Scholars and policymakers alike have devoted substantial energy to the problem of collective international action in monetary and trade policy and have recognized that "collective economic security" should accompany the commitments embodied in NATO and other collective security arrangements. As two scholars explain, "Broadly defined, collective economic security means governments' acceptance of international surveillance of their domestic and foreign economic policies, of criticism of the effects of their policies on the economic security of other countries, and of various forms of international presence in the operations of markets." Lawrence B. Krause \& Joseph S. Nye, Jr., Reflections on the Economics and Politics of International Economic Organizations, in WORLD POLITICS AND INTERNATIONAL ECONOMICS 323, 331 (C. Fred Bergsten \& Lawrence B. Krause eds., 1975).

149. See ARTHUR M. SCHLESINGer, JR., THE IMPERIAL PresidenCy (1973).

150. See, e.g., ROBERT F. TURNER, REPEALING THE WAR POWERS RESOLUTION: RESTORING THE RULE OF LAW IN U.S. FOREIGN POLICY (1991) (arguing that repeal would improve congressional-executive 
conceptual scheme nonetheless represents substantial agreement over the appropriate distribution of power in military crises. ${ }^{151}$ First, the War Powers Resolution highlights the Constitution's assignment to Congress of the power to declare war. Passed in response to perceived presidential unaccountability in Vietnam, the War Powers Resolution attempts to ensure that the decision to commit and maintain troops is made by the legislative branch, as the Framers plainly intended. ${ }^{152}$ The basic structure of the legislation, which provides the President with the independent authority to deploy troops abroad in conditions of latent or active hostilities, recognizes that the Commander in Chief Clause provides the President with some discretionary power to act without congressional preapproval. ${ }^{153}$

Congress has conceded such discretionary authority so that the President may carry out his duty to repel attacks and respond to immediate threats to national security. ${ }^{154}$ The sixty-day grant of discretion therefore constitutes the interstitial space between declaration of war-which is clearly a congressional power-and the enforcement power, which properly belongs to the President. Military deployments of less than sixty days are considered policing actions,

relationship and foster greater mutual respect and comity); Edward Keynes, The War Powers Resolution: A Bad Idea Whose Time Has Come and Gone, 23 U. ToL. L. REv. 343, 344 (1992) (suggesting that War Powers Resolution is an unconstitutional delegation of legislative power to President to declare war and should be repealed).

Critics of the War Powers Resolution complain that it unduly infringes on the President's ability to exercise his Commander in Chief powers in the protection of national security. See, e.g., Remarks of Abraham D. Sofaer, The War Powers Resolution: Fifteen Years Later, 62 TEMP. L. REV. 317, 326 (1989) (arguing that $\$ 5$ timing requirements of War Powers Resolution unconstitutionally restrain President from exercising executive duties). Even supporters of constraints on the President's warmaking powers have criticized the Resolution because they believe that it still leaves the President with too much discretion to introduce troops into hostilities and thus does not adequately protect Congress's exclusive power to declare war. See John Hart Ely, Suppose Congress Wanted a War Powers Act that Worked, 88 COLUM. L. REV. 1379,1399 (1988) (arguing that the 60-to 90-day period is so long that it "ceases to be an estimate of how long it will take Congress to consider the matter and becomes, instead, a delegation of legislative power to the President ... . so open-ended in fact as to raise serious constitutional problems"); David S. Friedman, Waging War Against Checks and Balances-The Claim of an Unlimited Presidential War Power, 57 ST. JOHN'S L. REV. 213, 264-65 (1983) (arguing that because only limit placed on presidential power is durational, War Powers Resolution places "no restraint on the initial exercise of war power" and "does nothing to reverse the usurpation" of congressional authority). Though as currently written the legislation has not been successful, many nonetheless believe that a viable War Powers Act is possible. "“If we choose to make it work, it will work."' Ely, supra, at 1379 (quoting 134 CONG. REC. S7173 (daily ed. June 6, 1988) (comments of Senate Foreign Relations Committee Chair Claibome Pell)).

151. The executive branch has never denied that Congress has the sole power to declare war. It has, however, fought vigorously to contract the definition of war to a point bordering on meaninglessness. See Sidak, supra note 142, at 39-40 (describing efforts of Bush administration to characterize Korean and Vietnam Wars, and thus Persian Gulf War, as "conflicts" not requiring congressional declaration of war).

152. See Ely, supra note 150 , at 1386.

153. See, e.g., 50 U.S.C. $\$ 1542$ (1988) (President in every possible instance shall consult with Congress before introducing U.S. armed forces into hostilities).

154. The President's inherent war powers start, and may stop, with "the powers to repel actual or imminent attacks upon the country or its armed forces and possibly to rescue U.S. citizens abroad." Cyrus R. Vance, Striking the Balance: Congress and the President Under the War Powers Resolution, 133 U. PA. L. REV. 79, 85 (1984). 
those of more than sixty days, wars. ${ }^{155}$ This compromise provides clear and separate roles for both Congress and the President in military crises and, in theory, allows both branches of government to exercise their appropriate constitutional functions. Undergirding the War Powers Resolution, and consonant with the Youngstown theory of separation of powers, is a highly constricted view of inherent presidential authority, identified by Jules Lobel as the "Liberal Paradigm of Emergency Power." 156 According to Lobel's Liberal Paradigm, "In war or emergency, the Executive has constitutional authority only when the emergency is physically forced upon the country and there is no option but to respond ...." ${ }^{57}$ This authority is consistent with the preservation of legislative policymaking discretion because "[r]esponding is not really a discretionary act" of the Executive under circumstances of extreme exigency. ${ }^{158}$

An application of the Liberal Paradigm to the realm of international economic crisis suggests a distribution of constitutional appropriation powers similar to that codified in the War Powers Resolution. Such a theory is premised on the assumption that "the constitutional conception of a Chief Executive authorized to enforce the laws includes a general authority to protect and defend the personnel, property, and instrumentalities of the United States from harm," 159 but also ensures that such powers remain "few and defined."160 Accordingly, framework legislation should be formulated allowing Congress to perform its institutional role of authorizing expenditures and should provide intelligible principles of law to which executive branch actors can conform their efforts to protect national economic security. As Bruce Ackerman and David Golove have noted, "Only effective frameworks will discourage Presidents, and their underlings, from supposing that the Constitution grants the executive branch a vast prerogative for unilateral foreign adventurism.", 161

While this is not the place to detail such legislation, the analysis above suggests that any law developed should allow the President to intervene quickly in economic affairs when necessary to safeguard national economic

155. See Stephen L. Carter, The Constitutionality of the War Powers Resolution, 70 VA. L. REv. 101, 101-02 (1984) ("The War Powers Resolution is nothing more or less than a congressional definition of the word 'war' in article I."); Ely, supra note 150, at 1399 n.58 ("A central contribution of the War Powers Resolution was to translate the Constitution's generalities into numbers.").

156. Jules Lobel, Emergency Power and the Decline of Liberalism, 98 YALE L.J. 1385, 1392 (1989).

157. Id. at 1391 n.27. As Lobel points out, this was the theory in both Ex parte Milligan, 71 U.S. (4 Wall.) 2, 126-27 (1866) (finding that Executive had constitutional emergency power to try civilians in military courts when civil courts were not functioning), and Mitchell v. Harmony, 54 U.S. (13 How.) 128 , 134 (1851) (holding that Executive had constitutional authorization to seize American property when such property was about to be seized by enemy during war).

158. Lobel, supra note 156 , at 1391 n.27.

159. Henry P. Monaghan, The Protective Power of the Presidency, 93 Colum. L. REv. 1, 11 (1993).

160. THE FEDERALIST No. 45, at 292 (James Madison) (Clinton Rossiter ed., 1961).

161. Bruce Ackerman \& David Golove, Is NAFTA Constitutional?, 108 HARV. L. Rev. 801, 929 (1995). 
security but should restrict the power to obligate funds from the Treasury for more than a reasonably brief time, since long-term obligations more clearly infringe on the congressional appropriations power. For instance, the legislation could authorize the President to act without congressional approval to make bridge loans of limited duration to foreign governments from an "Economic Security Fund." 162 The time period fixed-perhaps ninety days-should be the minimum period needed by Congress to consider fully the merits of a bailout package and vote on any appropriations. ${ }^{163}$ In order legally to gain access to monies, the President would have to submit to Congress a report detailing the nature of the economic crisis, the amount of funds committed, and the requested appropriation. The submission of the report would automatically authorize the appropriation and mark the beginning of the ninety-day period. If the President certified that emergency circumstances required a longer loan period, bridge loans could be authorized for up to 180 days without congressional approval. Generally, such loans would be bridged to IMF loans or other international loan packages, or extended by specific congressional legislation. In any case, the law would require, after the President has committed U.S. funds, that formal approval from Congress be obtained in order to extend the loans. In the absence of this approval, the President's power to continue the bailout would end. As with the War Powers Resolution, the timing mechanism should prevent the President from taking advantage of congressional inertia to conduct a maverick foreign policy.

\section{CONCLUSION}

Neither 31 U.S.C. $\S 5302$ nor the Constitution permits the President to extend vast amounts of emergency aid to a foreign nation without congressional authorization. However, the protection of "national economic security" requires that the President have some capacity to intervene in

162. The largest danger accompanying the establishment of an Economic Security Fund is the threat of its abuse, a problem known to bankers and insurers as "moral hazard." Unlike natural disasters, economic crises like that which precipitated the Mexican collapse are strongly influenced by factors subject to human control. Any govemment policy that mitigates the consequences of risk-taking behavior raises problems of moral hazard, because it may create perverse incentives for investors to assume uneconomical risk. If the United States (or the international community) institutionalizes bailouts of foreign nations suffering economic crises, it could encourage irresponsible fiscal behavior on the part of individual investors, banks, and governments. Some Senators have questioned the wisdom of creating such a fund on these grounds. "[T] he worst thing we could think about doing is participating in or creating some sort of fund to bail out countries around the world that get into trouble. I think that simply encourages getting in trouble." Mexican Peso Crisis, supra note 1, at 633 (comments of Sen. Faircloth). In the bailout package extended to Mexico, Secretary Rubin argued that the conditions attached to the bailout by the United States and the IMF were stringent enough that no government would freely choose a policy that would land its country in a similar position. Id. at 630 (testimony of Robert Rubin, Secretary of the Treasury).

163. See Ely, supra note 150 , at 1398 . While Ely notes in regard to the War Powers Resolution that "[t]he only legitimate theory that supports giving the President 60 free days is that it approximates the time it will take Congress to gather its thoughts," he argues that Congress does not need that much time in order to deliberate and thus supports a shorter, 30-day "free period." Id. at 1398. 
international financial crises when the integrity of the U.S. economy is at stake. The best way to balance the demands of law with those of national security is for Congress to draft legislation that creates, and limits, presidential power to intervene in such crises.

Critics will point out that the attempt to deter extralegal presidential action through the institutionalization of emergency power may encourage Presidents to make use of this new power more frequently, and in unexpected ways. As Professor Schlesinger argues, "the legal order would be better preserved if departures from it were frankly identified as such than if they were anointed with a factitious legality and thereby enabled to serve as constitutional precedents for future action." 164 According to this view, the fact of illegality deters extralegal actions, even when it will not altogether prevent them.

This is undoubtedly true, yet there remain good reasons to support the legislative regularization of executive authority to intervene in foreign economic crises. First, in moments of true crisis, bitter contests over legality may impede the effective exercise of authority. Second, as Michael Glennon has argued in a slightly different context, the provision of a legal framework formally expanding the powers of the President

is advisable because Presidents will probably assume the authority to act in such situations regardless of a lack of congressional authorization; thus Congress will be in a stronger position if it authorizes, rather than merely acquiesces in, their actions, for acquiescence would suggest that a President may constitutionally act without congressional authorization in still other situations not enumerated .... ${ }^{165}$

If a legal structure like the one suggested above had been in place, the President could not have carried out the Mexican bailout without the full deliberation and eventual approval of Congress. The Executive, nonetheless, would have had access to sufficient funds to stave off foreign economic collapse until Congress could reasonably consider and pass a bailout package.

Of course, a workable arrangement based on such an outline requires a substantial degree of cooperation between the executive and the legislative branches of government. Though this cooperation has not always materialized, the threat of noncooperation is not a sufficient reason to imbue the Presidency

164. SCHLESINGER, supra note 149, at 9; see also Korematsu v. United States, 323 U.S. 214, $245-46$ (1944) (Jackson, J., dissenting) ("[A] judicial construction of the due process clause that will sustain this order is a far more subtle blow to liberty than the promulgation of the order itself."); BANKS \& RAVENHANSEN, supra note 13, at 134 (arguing that rationalizing executive branch actions lacking any statutory authorization but an assertion of necessity "as an exercise of a nebulous inherent constitutional power-is far more damaging to the rule of law in the long run [than making such actions legal only after an ex post ratification by Congress] because it creates a constitutional basis and legal precedent of executive authority for similar executive actions in the future").

165. Glennon, supra note 106 , at 35 . 
with dramatically enhanced spending powers. Nor is the competitive struggle between the executive and legislative branches for predominance in national policymaking a sufficient reason to disregard the separation of powers doctrine. As Professor Harold Koh has aptly noted, "We must reject notions of either executive or congressional supremacy in foreign affairs in favor of more formal institutional procedures for power sharing, designed clearly to define constitutional responsibility and to locate institutional accountability." 166 Not only will the clear assignment of institutional roles discourage presidential usurpation of power, but, during times of crisis, it will also encourage a reluctant Congress to make hard policy choices when such choices are needed.

With the continued development of faster, larger, and more volatile financial markets and the steady increase in the number of nations meaningfully participating in the world economy, the United States inevitably will face crises similar to the Mexican collapse. Enabling the President to react in a way that is both effective and consistent with the dictates of democratic government is the logical response to the new international economic reality.

166. KoH, supra note 98 , at 6-7. 
, 